\title{
The Effect of Traditional Chinese Medicine on Neural Stem Cell Proliferation and Differentiation
}

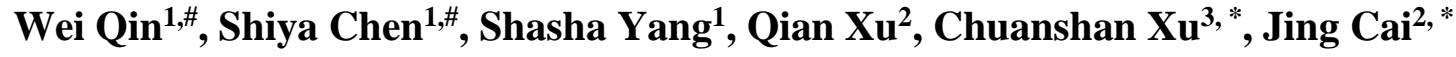 \\ ${ }^{1}$ Academy of Integrative Medicine, Fujian University of Traditional Chinese Medicine, Fuzhou 350122, China \\ ${ }^{2}$ College of Integrative Medicine, Fujian University of Traditional Chinese Medicine, Fuzhou 350122, China \\ ${ }^{3}$ School of Chinese Medicine, Faculty of Medicine, The Chinese University of Hong Kong, Shatin, Hong Kong
}

[Received December 28, 2016; Revised April 11, 2017; Accepted April 28, 2017]

\begin{abstract}
Neural stem cells (NSCs) are special types of cells with the potential for self-renewal and multidirectional differentiation. NSCs are regulated by multiple pathways and pathway related transcription factors during the process of proliferation and differentiation. Numerous studies have shown that the compound medicinal preparations, single herbs, and herb extracts in traditional Chinese medicine (TCM) have specific roles in regulating the proliferation and differentiation of NSCs. In this study, we investigate the markers of NSCs in various stages of differentiation, the related pathways regulating the proliferation and differentiation, and the corresponding transcription factors in the pathways. We also review the influence of TCM on NSC proliferation and differentiation, to facilitate the development of TCM in neural regeneration and neurodegenerative diseases.
\end{abstract}

Key words: Neural stem cells, proliferation, differentiation, traditional Chinese medicine

Both embryonic and adult neural stem cells (NSCs) are widely distributed in the nervous system. Embryonic NSCs are widely distributed in the brain, while adult NSCs are mainly distributed in the subventricular zone (SVZ) of the lateral ventricle wall and the subgranular zone (SGZ) of the hippocampus dentate gyrus [1, 2]. NSCs go through different stages of neural progenitor cells (NSPCs), neural precursor cells (NPCs), and neuroblasts in the process of proliferation and differentiation into neural cell lineage [3-7]. In the research on NSCs, their identification and differentiation in these stages are related to whether they can be accurately induced, differentiated, and migrated. The corresponding markers of NSCs at different stages have been identified and confirmed, and are summarized in this study.
NSCs can differentiate into different types of neural cells under specific conditions, which can provide new methods of cerebral injury repair and neurological disease treatment. Numerous studies have shown that NSCs have a therapeutic effect on nervous system injuries and degenerative diseases such as Alzheimer's disease (AD), Parkinson's disease (PD), spinal injury, amyotrophic lateral sclerosis (ALS), vascular dementia, cerebral hemorrhage, and Huntington's disease [8-17]. However, the differences between animal models and human diseases mean that the clinical application of stem cell therapy is still some way off.

Traditional Chinese medicine (TCM) has the general advantages of multi-targets, multi-levels, and multi-paths [18-21]. It can regulate NSC proliferation and differentiation by changing the microenvironment of

*Correspondence should be addressed to: Dr. Jing Cai, Academy of Integrative Medicine, Fujian University of Traditional Chinese

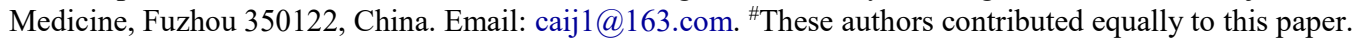

Copyright: ( 2017 Qin W et al. This is an open-access article distributed under the terms of the Creative Commons Attribution License, which permits unrestricted use, distribution, and reproduction in any medium, provided the original author and source are credited. 
NSCs and indirectly regulating endogenous and exogenous factors. Studies have shown that single herbs, herb extracts/Chinese herbal monomers and compounds, and Chinese medicinal preparations have, to some extent, a role in regulating NSC proliferation and differentiation [22-27].

Table 1. Markers of stem cell proliferation and differentiation in different stages.

\begin{tabular}{|c|c|c|c|c|}
\hline Marker & Property & $\begin{array}{l}\text { Affected } \\
\text { cell type }\end{array}$ & Function & Refs. \\
\hline Hopx & $\begin{array}{l}\text { atypical homeodomain } \\
\text { only protein }\end{array}$ & NSCs & $\begin{array}{l}\text { regulates hippocampal neurogenesis by modulating Notch } \\
\text { signaling }\end{array}$ & {$[33]$} \\
\hline Hes3 & $\begin{array}{l}\text { basic helix-loop- helix } \\
\text { gene }\end{array}$ & NSCs & $\begin{array}{l}\text { promote the proliferation of NSCs } \\
\text { maintain the undifferentiated state of NSCs }\end{array}$ & {$[34,35]$} \\
\hline TRIP6 & zyxin family proteins & NSCs & promote the self-renewal and proliferation of NSCs & {$[36]$} \\
\hline CycE & cyclin & NSCs & regulate neurogenesis in the adult hippocampus & [37] \\
\hline JAM-C & surface protein & NSCs & maintain the pluripotency of NSCs & [38] \\
\hline PtdGlc & lipid & NSCs & identify, isolate, and differentiate NSCs & [39] \\
\hline CD9 & transmembrane protein & NSPCs & $\begin{array}{l}\text { have an impact on the cell adhesion, migration, proliferation } \\
\text { and differentiation }\end{array}$ & {$[40,41]$} \\
\hline CD15 & transmembrane protein & NSPCs & $\begin{array}{l}\text { promote the survival of NSCs; } \\
\text { promote the differentiation of NSCs into oligodendroglia }\end{array}$ & {$[40,42]$} \\
\hline CD81 & transmembrane protein & NSPCs & control the cell migration & {$[40,43]$} \\
\hline S100 & $\begin{array}{l}\text { acid calcium binding } \\
\text { protein }\end{array}$ & NSPCs & regulate the proliferation of NSCs & [44] \\
\hline CD133 & transmembrane protein & NPCs & $\begin{array}{l}\text { promote the expansion of NSCs in vitro and its degree of } \\
\text { specialization }\end{array}$ & {$[45,46]$} \\
\hline $\mathrm{CD} 24$ & transmembrane protein & NPCs & $\begin{array}{l}\text { play an important role in self-renewal; } \\
\text { maintain NSCs }\end{array}$ & $\begin{array}{l}{[45,47,} \\
48]\end{array}$ \\
\hline Pax2 & paired box gene & NPCs & regulate the migration and proliferation of nerve cells & [49] \\
\hline NG2 & $\begin{array}{l}\text { transmembrane } \\
\text { proteoglycan }\end{array}$ & NPCs & regulate the migration of the oligodendrocyte precursor cells & {$[50,51]$} \\
\hline Nestin & $\begin{array}{l}\text { intermediate filaments } \\
\text { protein cytoskeletal } \\
\text { protein }\end{array}$ & $\begin{array}{l}\text { NSCs and } \\
\text { NSPCs }\end{array}$ & $\begin{array}{l}\text { be a marker for proliferating or migrating cells; } \\
\text { participate in cytoskeleton formation; } \\
\text { remodel cells along with other structural proteins; }\end{array}$ & {$[52-55]$} \\
\hline Musashi1 & RNA- binding protein & $\begin{array}{l}\text { NSCs and } \\
\text { NSPCs }\end{array}$ & $\begin{array}{l}\text { determine the fate of stem cells; } \\
\text { maintain the undifferentiated state of NSCs or NSPCs; }\end{array}$ & {$[56-61]$} \\
\hline Tub-II & cytoskeleton protein & $\begin{array}{l}\text { NSCs and } \\
\text { NSPCs }\end{array}$ & reflect the structural changes in the development of the brain & {$[62,63]$} \\
\hline SOX2 & $\begin{array}{l}\text { high-mobility group } \\
\text { proteins }\end{array}$ & $\begin{array}{l}\text { NSCs and } \\
\text { NSPCs }\end{array}$ & $\begin{array}{l}\text { play a role in self-renewal and maintenance of NSCs; } \\
\text { prevent the apoptosis of NSCs. }\end{array}$ & $\begin{array}{l}{[56,64,} \\
65]\end{array}$ \\
\hline SOX1 & $\begin{array}{l}\text { high-mobility group } \\
\text { proteins }\end{array}$ & $\begin{array}{l}\text { NSCs and } \\
\text { NSPCs }\end{array}$ & promote the self-renewal of NSCs & [66-68] \\
\hline $\operatorname{Sp} 8$ & zinc finger protein & $\begin{array}{l}\text { NSCs and } \\
\text { NSPCs }\end{array}$ & maintain the undifferentiated state of NSCs & {$[69,70]$} \\
\hline S100A6i & $\begin{array}{l}\text { low-molecular-weight } \\
\text { calcium-binding proteins }\end{array}$ & $\begin{array}{l}\text { NSCs and } \\
\text { NPCs }\end{array}$ & $\begin{array}{l}\text { promote the neurogenesis in the hippocampus; } \\
\text { play an important role in the differentiation and maturation } \\
\text { of astrocytes }\end{array}$ & [71] \\
\hline Prox1 & $\begin{array}{l}\text { homeobox transcription } \\
\text { factor }\end{array}$ & neuroblasts & $\begin{array}{l}\text { play an important role in regulating the proliferation and } \\
\text { differentiation of NSCs; } \\
\text { maintain the intermediate progenitor cells }\end{array}$ & {$[72,73]$} \\
\hline Cyc D1 & cyclin & neuroblasts & $\begin{array}{l}\text { promote the proliferation of NSCs; } \\
\text { inhibit their differentiation }\end{array}$ & $\begin{array}{l}{[74,75,} \\
204]\end{array}$ \\
\hline DCX & $\begin{array}{l}\text { microtubule-associated } \\
\text { protein }\end{array}$ & neuroblasts & regulate the migration of neural cells & {$[76,77]$} \\
\hline
\end{tabular}

The table lists the markers of NSCs proliferation and differentiation, the property of the markers, the cell type they affect, and their function in NSC proliferation and differentiation: Tub-II, tubulin beta II; SOX2, sex-determining region Y-box2; SOX1, sex-determining region Y-box1; Sp8, specificity protein 8; PAX2, paired box protein 2; Hopx , homeodomain only protein X; Hes3, hairy and enhancer of split 3; TRIP6, thyroid receptor-interacting protein 6; CycE, cyclinE;JAM-C, junctional adhesion molecule-C; PtdGlc, phosphatidylglucoside; S100 $\beta$, S100 calcium-binding protein B; NG2, Neuron glia antigen 2; Cyc D1, Cyclin D1; Prox1, prospero homeobox protein 1; DCX, doublecortin; NSCs, neural stem cells; NSPCs, neural progenitor cells; NPCs, neural precursor cells. 
In this article, we discuss the regulation of NSC proliferation and differentiation by the relevant pathways and the target genes corresponding to the pathways, and review the effects of TCM on the proliferation and differentiation of NSCs, to further develop the study of NSC proliferation and differentiation by TCM.

Table 2. The main transcription factors and associated signaling pathways in NSC proliferation and differentiation.

\begin{tabular}{|c|c|c|c|c|c|c|c|}
\hline TFs & $\begin{array}{l}\text { Protein } \\
\text { family }\end{array}$ & Pathway & $\begin{array}{l}\text { In vivo } \\
\text { or in } \\
\text { vitro } \\
\end{array}$ & Effect on NSCs & $\begin{array}{l}\text { Affected } \\
\text { cell type }\end{array}$ & $\begin{array}{l}\text { Location of } \\
\text { expression }\end{array}$ & Refs. \\
\hline Hes 1 & bHLH & Notch & $\begin{array}{l}\text { In vivo } \\
\text { and in } \\
\text { vitro }\end{array}$ & $\begin{array}{l}\text { Play a role in maintenance of NSCs; } \\
\text { Inhibit the differentiation of NSCs into } \\
\text { neurons; Have an effect on the } \\
\text { maintenance and self-renewal of NSPCs }\end{array}$ & $\begin{array}{l}\text { NSCs and } \\
\text { NSPCs }\end{array}$ & SVZ, SGZ & {$[81-87]$} \\
\hline Hes5 & bHLH & Notch & In vitro & promote the proliferation of NSCs & $\begin{array}{l}\text { NSCs and } \\
\text { NSPCs }\end{array}$ & SVZ & [88-90] \\
\hline Mash1 & bHLH & Notch & $\begin{array}{l}\text { In vivo } \\
\text { and in } \\
\text { vitro }\end{array}$ & Promote the differentiation of NPCs & $\begin{array}{l}\text { NSPCs } \\
\text { and NPCs }\end{array}$ & SVZ, SGZ & {$[91-96]$} \\
\hline NeuroD & bHLH & Notch & $\begin{array}{l}\text { In vivo } \\
\text { and in } \\
\text { vitro }\end{array}$ & $\begin{array}{l}\text { Determine the fate and differentiation of } \\
\text { cells; Determine the survival of neurons }\end{array}$ & $\begin{array}{l}\text { NSPCs } \\
\text { and NPCs }\end{array}$ & $\begin{array}{l}\text { SGZ, SVZ, } \\
\text { VZ }\end{array}$ & {$[97-102]$} \\
\hline zfp488 & ZFP & Notch & In vivo & $\begin{array}{l}\text { Promote the differentiation of NSCs into } \\
\text { the oligodendrocytes }\end{array}$ & $\begin{array}{l}\text { NSCs and } \\
\text { NSPCs }\end{array}$ & SVZ & $\begin{array}{l}{[103,} \\
104]\end{array}$ \\
\hline Ngn1 & bHLH & Notch & In vivo & $\begin{array}{l}\text { Promote neurogenesis; } \\
\text { Play a specific role in the maintenance of } \\
\text { NSPCs; Promote the differentiation of } \\
\text { NPCs in vivo }\end{array}$ & $\begin{array}{l}\text { NSPCs } \\
\text { and NPCs }\end{array}$ & SVZ & $\begin{array}{l}{[105,} \\
106]\end{array}$ \\
\hline Ngn2 & bHLH & Notch & $\begin{array}{l}\text { In vivo } \\
\text { and in } \\
\text { vitro }\end{array}$ & $\begin{array}{l}\text { Play a regulatory role in neurogenesis; } \\
\text { Control the balance of the maintenance } \\
\text { and differentiation of NSPCs }\end{array}$ & NSPCs & VZ, SVZ & $\begin{array}{l}{[107,} \\
108]\end{array}$ \\
\hline Fezf2 & ZFP & Notch & $\begin{array}{l}\text { In vivo } \\
\text { and in } \\
\text { vitro }\end{array}$ & $\begin{array}{l}\text { Has a role in the maintenance and } \\
\text { differentiation of NSCs }\end{array}$ & $\begin{array}{l}\text { NSCs, } \\
\text { NSPCs } \\
\text { and NPCs }\end{array}$ & SVZ, VZ & $\begin{array}{l}{[109} \\
110]\end{array}$ \\
\hline Hey1 & bHLH & Notch & In vivo & Play a role in the maintenance of NSCs & NPCs & VZ, SVZ & [111-113] \\
\hline Gsx2 & HOM & Notch & In vivo & $\begin{array}{l}\text { Reduce the ability of NSCs to proliferate } \\
\text { and self-renew; } \\
\text { Reduce the transformation of NSCs into } \\
\text { neurons and glial cells }\end{array}$ & $\begin{array}{l}\text { NSCs and } \\
\text { NSPCs }\end{array}$ & SVZ, VZ & [114-116] \\
\hline Pax6 & $\mathrm{HOM}$ & Wnt & $\begin{array}{l}\text { In vivo } \\
\text { and in } \\
\text { vitro }\end{array}$ & $\begin{array}{l}\text { Control the balance of the maintenance } \\
\text { and differentiation of NSCs; } \\
\text { Play an important role in maintenance, } \\
\text { self-renewal and multi-directional } \\
\text { differentiation of NSCs }\end{array}$ & $\begin{array}{l}\text { NSCs and } \\
\text { NSPCs }\end{array}$ & $\begin{array}{l}\text { SVZ, OB, } \\
\text { SGZ, VZ }\end{array}$ & [121-126] \\
\hline Emx2 & $\mathrm{HOM}$ & Wnt & $\begin{array}{l}\text { In vivo } \\
\text { and in } \\
\text { vitro }\end{array}$ & $\begin{array}{l}\text { Control the proliferation and migration of } \\
\text { NPC }\end{array}$ & $\begin{array}{l}\text { NSCs and } \\
\text { NPCs }\end{array}$ & SVZ, VZ & [127-129] \\
\hline Dix2 & HOM & Wnt & $\begin{array}{l}\text { In vivo } \\
\text { and in } \\
\text { vitro }\end{array}$ & $\begin{array}{l}\text { Promote the neurogenesis and } \\
\text { proliferation }\end{array}$ & NPCs & SVZ, OB & $\begin{array}{l}{[130,} \\
131]\end{array}$ \\
\hline Pax3 & $\mathrm{HOM}$ & Wnt & $\begin{array}{l}\text { In vivo } \\
\text { and in } \\
\text { vitro }\end{array}$ & $\begin{array}{l}\text { Regulate the differentiation of NSCs; } \\
\text { Determine the fate of cells; Maintain the } \\
\text { undifferentiated state of NSCs. }\end{array}$ & NSPCs & $\mathrm{VZ}$ & [132-137] \\
\hline Oct4 & POU & Wnt & $\begin{array}{l}\text { In vivo } \\
\text { and in } \\
\text { vitro }\end{array}$ & $\begin{array}{l}\text { Play an important role in the maintenance } \\
\text { of the pluripotency of NSCs; } \\
\text { Promote the proliferation and self-renewal } \\
\text { of NSCs }\end{array}$ & NSCs & SVZ & [138-140] \\
\hline Prox1 & HOM & Wnt & $\begin{array}{l}\text { In vivo } \\
\text { and in } \\
\text { vitro }\end{array}$ & $\begin{array}{l}\text { Promote the proliferation of NSCs; } \\
\text { Play an important role in the maintenance } \\
\text { of intermediate progenitor cells }\end{array}$ & NSPCs & SGZ & $\begin{array}{l}{[141,} \\
142]\end{array}$ \\
\hline Nkx2.2 & $\mathrm{HOM}$ & Shh & In vivo & $\begin{array}{l}\text { Promote the differentiation of } \\
\text { oligodendrocytes }\end{array}$ & $\begin{array}{l}\text { NSPCs } \\
\text { and NPCs }\end{array}$ & SVZ, OB & [152-156] \\
\hline
\end{tabular}




\begin{tabular}{|c|c|c|c|c|c|c|c|}
\hline Gli-1 & ZFP & Shh & $\begin{array}{l}\text { In vivo } \\
\text { and in } \\
\text { vitro }\end{array}$ & Promote the proliferation of NPCs & NPCs & SVZ, SGZ & {$[158-162]$} \\
\hline Sox 2 & HMG & BMP & $\begin{array}{l}\text { In vivo } \\
\text { and in } \\
\text { vitro }\end{array}$ & $\begin{array}{l}\text { Play a role in self-renewal and } \\
\text { maintenance of NSCs; } \\
\text { Prevent the apoptosis of NSCs }\end{array}$ & $\begin{array}{l}\text { NPCs and } \\
\text { NSCs }\end{array}$ & $\begin{array}{l}\text { SVZ, SGZ, } \\
\text { VZ }\end{array}$ & {$[167-172]$} \\
\hline Olig2 & bHLH & BMP & $\begin{array}{l}\text { In vivo } \\
\text { and in } \\
\text { vitro }\end{array}$ & $\begin{array}{l}\text { Induce the differentiation of NSCs into } \\
\text { oligodendrocytes; } \\
\text { Promote the maturation of the } \\
\text { differentiated cells. }\end{array}$ & NSPCs & SVZ & {$[173-175]$} \\
\hline \multicolumn{8}{|c|}{$\begin{array}{l}\text { The table lists the main transcription factors and associated signaling pathways in NSC proliferation and differentiation, the protein family the } \\
\text { transcription factors belong to, the cell type, they influence and their effect on NSCs proliferation and differentiation, and the main location of their } \\
\text { expression. Hes1, hairy, and enhancer of split 1; Hes5, hairy and enhancer of split 5; Mash1, achaete-scute homolog 1; NeuroD, neurogenic } \\
\text { differentiation factor-6; zfp488zinc finger protein 488; Ngn1,Neurogenin1; Ngn2, Neurogenin2; Fezf2, forebrain embryonic zinc finger 2; Gsx2, GS } \\
\text { Homeobox 2; Hey1, hairy/enhancer-of-split related with YRPW motif protein 1; Pax6, paired box protein 6; Pax3, paired box protein 3; Emx2, empty } \\
\text { spiracles homeobox 2; Dix2, distal-less homeobox 2; oct4, octamer-binding transcription factor 4; Olig2, oligodendrocyte lineage transcription factor } \\
\text { 2; Nkx2.2,NK2 homeobox 2;Gli-1, glioma associated oncogene-1; bHLH, basic helix-loop-helix; HOM, homedomain; HMG, high mobility group; } \\
\text { PC, Polycomb; ZFP, zinc finger proteins; BMP, bone morphogenetic protein; Shh, sonic hedgehog; SVZ, subventricular zone; SGZ, dentate gyrus } \\
\text { subgranular zone; VZ, ventricular zone; OB, olfactory bulb. }\end{array}$} \\
\hline
\end{tabular}

\section{The stages and related markers of NSC proliferation and differentiation}

NSCs go through different stages of NSPCs, NPCs, and neuroblasts in the process of proliferation and differentiation into mature neural cells [28-32]. NSCs can express specific molecular markers in the proliferation and differentiation stages. These markers have the function of selectively binding to signal molecules and are involved in the expression of cell signaling. In addition, transcription factors and cell adhesion molecules are significant for the differentiation of NSCs. The Nestin, Musashi1, sex-determining region Y-box2 (SOX2), Prox 1 , and $\mathrm{CD}$ family proteins are the most common markers.

An increasing number of novel markers have also been used to identify NSCs. These include homeodomainonly protein X (Hopx) [33], hairy and enhancer of split 3 (Hes3) [34, 35], thyroid receptor-interacting protein 6 (TRIP6) [36], Cyclin E (CycE) [37], junctional adhesion molecule-C (JAM-C) [38], and phosphatidylglucoside (PtdGlc) [39], which are mainly expressed in NSCs and can be used as characteristic markers. The expression of CD9 [40, 41], CD15 [40, 42], CD81 [40, 43], and S100 calcium-binding protein B (S100ß) [44] are commonly expressed in NSPCs. The same CD family members CD133 [45, 46] and CD24 [45, 47, 48], paired box protein 2 (Pax2) [49] of the paired box gene family, and transmembrane proteoglycan (NG2) $[50,51]$ are mainly expressed in NPCs. Nestin [52-56], Musashi1 [56-61], cytoskeleton protein (Tub-II ) [62, 63], sex-determining region Y-box2 (SOX2) [56, 64, 65], sex-determining region Y-box1 (SOX1) [66-68], specificity protein 8 (Sp8) $[69,70]$, and low-molecular-weight calcium-binding proteins (S100A6i ) [71] are expressed in both NSCs and NSPCs, while prospero homeobox protein 1 (Prox1) [72,
73], Cyclin D1 (CycD1) [74, 75], and doublecortin (DCX) $[76,77]$ are expressed in the neuroblast. The properties of the related markers, the stage of the labeled cells, and the function of the markers are summarized in Table 1.

\section{Signaling pathways and major transcription factors involved in NSC proliferation and differentiation}

Multiple signaling pathways regulate the process of NSCs proliferating and differentiating into mature neurons. These pathways determine the fate of NSCs by regulating the expression and activity of different transcription factors, and many pathways are involved. The Notch, Wnt, bone morphogenetic protein (BMP), and sonic hedgehog (shh) signal pathways have been most studied. Downstream of the signal pathway are usually target genes that can be used as transcription factors to regulate the process of proliferation, differentiation, and migration of NSCs, and different signaling pathways and transcription factors can act synergistically to regulate this process. These are summarized in Table 2 .

\subsection{The Notch signaling pathway}

The Notch gene was originally found by Morgan and colleagues in drosophila in 1917 [78]. The partial deletion of this gene function was found to lead to a gap in the wing edge of drosophila. The Notch signaling pathway is a highly conserved pathway, which is widespread in invertebrates and mammals, and it determines the fate of cells by precisely regulating cells growth, differentiation, and apoptosis [79]. Numerous studies have shown that the Notch signaling pathway plays an important role in the proliferation and differentiation of NSCs, particularly for maintaining an undifferentiated state and the ability for self-renewal [80]. The common target genes of the pathway are the hairy and enhancer of split 1 (Hes1), hairy 
and enhancer of split (Hes5), achaete-scute homolog 1 (Mash1), neurogenic differentiation factor-6 (NeuroD), zinc finger protein 488 (zfp488), Neurogenin1 (Ngn1), Neurogenin2 (Ngn2), forebrain embryonic zinc finger 2 (Fezf2), GS Homeobox 2 (Gsx2), hairy/enhancer-of-split related with YRPW motif protein 1 (Hey1), etc. These transcription factors play an important role in the regulation of NSCs proliferation and differentiation. Hes1, Hes5, Mash1, NeuroD, zfp488, Ngn1, Ngn2, and Hey1, are members of the basic helix-loop-helix (bHLH) gene family, which can play a role in the regulation of NSCs in vivo and in vitro. Hes1 is mainly expressed in the SVZ. It can maintain the state of NSCs, inhibit their differentiation into neurons, and also have an effect on the maintenance and self-renewal of NSPCs [81-87]. Hes5 can promote the proliferation of NSCs, which is mainly expressed in SVZ [88-90]. Mash1 is a target gene of the Notch signaling pathway, which can be expressed in SVZ and SGZ during neurogenesis. Mash1 is also a determinant for the differentiation and maturation of neural in vivo and in vitro. Studies have shown that Mash1 promote the differentiation of NSPCs and NPCs [91-96]. NeuroD, a member of the bHLH gene family, can determine the fate and differentiation of cells. It is mainly expressed in SGZ, which regulate neurogenesis in vivo and in vitro [97-102]. zfp488 promotes the differentiation of NSCs into oligodendrocytes [103, 104]. Ngn1 and Ngn2 are the other two bHLH family genes, and Ngn1 can promote neurogenesis and the differentiation of NPCs in vivo. It also plays a specific role in the maintenance of NSPCs $[105,106]$. Ngn2 can be expressed in SVZ and the ventricular zone (VZ) during neurogenesis, and plays a regulatory role in neurogenesis in vivo and in vitro. Ngn2 also controls the balance between the maintenance and differentiation of NSPCs [107, 108]. Fezf2 is a zinc finger transcription factor, and research has shown that it can promote the differentiation of NSCs in SVZ. It also influences the maintenance of NSCs [109, 110]. Hey1 has a maintenance effect on NSCs, which is mainly expressed in VZ and SVZ [111-113]. Gsx2 is a homeodomain transcription factor, which is mainly expressed in SVZ. Gsx2 plays an important role in the inhibition of neurogenesis. For example, Gsx2 can reduce the proliferation and self-renewal of NSCs, and inhibit the differentiation of NSCs into neurons and glial cells. Thus, the NSCs and NSPCs can be maintained in a static and undifferentiated state [114-116].

\subsection{Wnt signaling pathway}

The Wnt signaling pathway is named after its promoter protein Wnt, which is synthesized by the wingless gene of the African drosophila and the proto-oncogene Int1 of the mouse. The four main Wnt signal pathways are the canonical Wnt/ $\beta$-catenin pathway, the Wnt/polarity pathway, the $\mathrm{Wnt} / \mathrm{Ca}^{2+}$ pathway, and the intracellular pathways that regulate spindle orientation and asymmetric cell division [117]. Of these, the canonical Wnt/ $\beta$-catenin signaling pathway is important in regulating the proliferation and differentiation of NSCs [118-120]. The target genes regulated by the Wnt signaling pathway are paired box protein 6 (Pax6), paired box protein 3 (Pax3), empty spiracles homeobox 2 (Emx2), distal-less homeobox 2 (Dix2), Octamer-binding transcription factor 4 (Oct4), Prox1, etc. Pax6, Emx2, Dix2, Pax3, and Prox1 belong to the zinc finger transcription factor. Pax6 regulates the proliferation and differentiation of NSCs in vivo and in vitro. Studies have shown that Pax6 can be expressed in both SVZ and OB, and can control the balance between the self-renewal and differentiation of NSCs, and is important in their maintenance, self-renewal, and multi-directional differentiation [121-126]. Emx2 is a target gene regulated by the Wnt signaling pathway, which regulates neurogenesis in vivo and in vitro. Emx2 mainly affects NPCs through controlling the migration and differentiation of NPCs [127-129]. Dix2 is expressed in SVZ and OB, and regulates the proliferation of NPCs in SVZ [130, 131]. Pax3 is a DNA-binding protein, mainly expressed in VZ, and plays a role in the maintenance of NSPCs. The overexpression of Pax 3 can inhibit the differentiation of NSCs. But if it is inhibited, it will promote their differentiation [132-137]. Oct4 belongs to the POU protein family, and can be expressed in vivo and in vitro. Oct4 is important in the maintenance of pluripotent stem cells, and promotes the proliferation and self-renewal of NSCs [138-140]. Prospero homeobox protein 1 (Prox 1) plays an important role in the maintenance of NSPCs and regulates the differentiation of NSCs in SGZ [141, 142].

\subsection{Shh signaling pathway}

The hedgehog gene was first found in Drosophila in 1980, and has three homologous genes: sonic hedgehog (Shh), Indian hedgehog (Ihh), and desert hedgehog (Dhh). They encode Shh, Ihh, and Dhh proteins, respectively [143145]. The Sonic hedgehog is an important developmental regulatory factor produced by the notochord during embryonic development [146]. Shh is important in regulating the migration, survival, and proliferation of NSCs [147-149]. The Shh signaling pathway can regulate the self-renewal of NSCs by increasing their symmetrical division [150, 151]. NK2 homeobox $2(\mathrm{Nkx} 2.2)$ is an important transcription factor involved in the regulation of the Shh pathway. Nkx2.2 can be expressed in both SVZ and $\mathrm{OB}$, and can promote the differentiation of oligodendrocytes and inhibit their self-renewal ability [152-157]. Glioma-associated oncogene-1 (Gli-1) is a 
member of the ZFP protein family and a target gene of the Shh pathway, which can be expressed in vivo and in vitro and promote the proliferation of NPCs [158-162].

Table 3. Effects of single herb and compound Chinese medicinal preparations on NSC proliferation and differentiation.

\begin{tabular}{|c|c|c|c|c|c|c|}
\hline Classification & TCM & $\begin{array}{l}\text { Affected } \\
\text { cell type }\end{array}$ & Effect on NSCs & Main mechanisms & $\begin{array}{l}\text { In vivo or in } \\
\text { vitro }\end{array}$ & Refs \\
\hline \multirow{6}{*}{$\begin{array}{l}\text { Compound } \\
\text { Chinese } \\
\text { medicinal } \\
\text { preparations }\end{array}$} & $\begin{array}{l}\text { BuyangHuanwu } \\
\text { Decoction }\end{array}$ & $\begin{array}{l}\text { NSCs and } \\
\text { NSPCs }\end{array}$ & $\begin{array}{l}\text { Promote the proliferation } \\
\text { and differentiation of } \\
\text { NSCs and NSPCs }\end{array}$ & $\begin{array}{l}\text { Decrease the content of } \\
\mathrm{Ca}^{2+} \text { in the cells, and } \\
\text { increase the expression } \\
\text { of NF and GFAP. }\end{array}$ & $\begin{array}{l}\text { In vivo and in } \\
\text { vitro }\end{array}$ & $\begin{array}{l}{[177} \\
179]\end{array}$ \\
\hline & Jiawei Sini San & NPCs & $\begin{array}{l}\text { Promote the proliferation } \\
\text { of NPCs and inhibit } \\
\text { apoptosis }\end{array}$ & $\begin{array}{l}\text { The expression of } \\
\text { nestin, beta-tubulin-III, } \\
\text { and fibrillary acidic } \\
\text { protein glial were } \\
\text { significantly increased }\end{array}$ & In vitro & {$[180$} \\
\hline & Shengyu decoction & $\begin{array}{l}\text { NSCs and } \\
\text { NSPCs }\end{array}$ & $\begin{array}{l}\text { Promote the proliferation } \\
\text { of NSCs/NSPCs and their } \\
\text { differentiation into } \\
\text { neurons }\end{array}$ & $\begin{array}{l}\text { Increase the expression } \\
\text { of TN-C, GDNF, } \\
\text { NCAM, and NGF, and } \\
\text { inhibits the expression } \\
\text { of Nogo-A }\end{array}$ & In vivo & {$[181]$} \\
\hline & FuzhiSan & NSPCs & $\begin{array}{l}\text { Promote the proliferation } \\
\text { of NSPCs; Improve the } \\
\text { survival rate of newborn } \\
\text { cells }\end{array}$ & $\begin{array}{l}\text { Promote the } \\
\text { neurogenesis in } \\
\text { hippocampus }\end{array}$ & In vivo & {$[182$} \\
\hline & XiehuoBushenDecocfion & NSCs & $\begin{array}{l}\text { Promote the survival and } \\
\text { differentiation of NSCs }\end{array}$ & $\begin{array}{l}\text { Enhance the expression } \\
\text { of IL- } 4 \text { mRNA, and } \\
\text { down-regulate the } \\
\text { expression of IFN-gama } \\
\text { mRNA }\end{array}$ & $\begin{array}{l}\text { In vivo and in } \\
\text { vitro }\end{array}$ & [27] \\
\hline & PMC-12 & NSPCs & $\begin{array}{l}\text { Promote the proliferation } \\
\text { of NSPCs in the } \\
\text { hippocampus; } \\
\text { Improve the survival rate } \\
\text { of newborn nerve cells }\end{array}$ & $\begin{array}{l}\text { Increased levels of } \\
\text { BDNF, p-CREB and } \\
\text { synaptophysin }\end{array}$ & In vivo & {$[183$} \\
\hline \multirow{3}{*}{ Single herb } & Salvia miltiorrhiza Bge & NSCs & $\begin{array}{l}\text { Promote the } \\
\text { differentiation of induced } \\
\text { multifunctional NSCs } \\
\text { into neurons in vitro; } \\
\text { Promote the survival, } \\
\text { collection and } \\
\text { differentiation of NSCs } \\
\text { derived from } \\
\text { multifunctional stem cell }\end{array}$ & $\begin{array}{l}\text { Increase the expression } \\
\text { of nestin and } \\
\text { MAP2 }\end{array}$ & $\begin{array}{l}\text { In vivo and in } \\
\text { vitro }\end{array}$ & [22] \\
\hline & $\begin{array}{l}\text { Sambucus williamsii } \\
\text { Hance }\end{array}$ & NSCs & $\begin{array}{l}\text { Promotethe } \\
\text { differentiationof NSCs } \\
\text { into neurons }\end{array}$ & $\begin{array}{l}\text { Up-regulate the } \\
\text { expression of Tuj1 and } \\
\text { nestin genes, and down- } \\
\text { regulate the expression } \\
\text { of Oct4 and Sox } 2 \text { genes }\end{array}$ & In vitro & {$[184$} \\
\hline & $\begin{array}{l}\text { Scutellariacalensis } \\
\text { Georgi, } \\
\text { Phellodendronchinense } \\
\text { Schneid, } \\
\text { Ligusticumwallichii } \\
\text { Franch }\end{array}$ & $\begin{array}{l}\text { NSCs and } \\
\text { NPCs }\end{array}$ & $\begin{array}{l}\text { Promote the proliferation } \\
\text { of NSCs and NPCs }\end{array}$ & $\begin{array}{l}\text { Modulate HPA axis and } \\
\text { increase the content of } \\
\text { corticosterone }\end{array}$ & $\begin{array}{l}\text { In vivo and in } \\
\text { vitro }\end{array}$ & [23] \\
\hline
\end{tabular}


Table 4. Effects of active components of Chinese herbs on NSC proliferation and differentiation.

\begin{tabular}{|c|c|c|c|c|c|c|c|}
\hline $\begin{array}{l}\text { Effective } \\
\text { components } \\
\text { of Chinese } \\
\text { herbs } \\
\end{array}$ & Origin & $\begin{array}{l}\text { Categories } \\
\text { of Chinese } \\
\text { herbs }\end{array}$ & $\begin{array}{l}\text { Affected } \\
\text { cell type }\end{array}$ & Effects & $\begin{array}{l}\text { Underlying } \\
\text { mechanisms }\end{array}$ & $\begin{array}{l}\text { In vivo } \\
\text { or in } \\
\text { vitro }\end{array}$ & Refs. \\
\hline $\begin{array}{l}\text { Ginsenoside } \\
\text { Rg1 }\end{array}$ & $\begin{array}{l}\text { Panax ginseng C. A. } \\
\text { Mey }\end{array}$ & $\begin{array}{l}\text { Tonifying Qi } \\
\text { herbs }\end{array}$ & $\begin{array}{l}\text { NSCs } \\
\text { and } \\
\text { NSPCs }\end{array}$ & $\begin{array}{l}\text { Promote the } \\
\text { differentiation of } \\
\text { NSCs and NSPCs }\end{array}$ & $\begin{array}{l}\text { Increase the expression } \\
\text { of SOX- } 2 \text { and decrease } \\
\text { the expression of IL- } 1 \beta \text {, } \\
\text { IL- } 6 \text { and TNF- } \alpha \text {; } \\
\text { Enhance the role of anti- } \\
\text { inflammatory and } \\
\text { antioxidant }\end{array}$ & In vivo & $\begin{array}{l}{[186,} \\
187]\end{array}$ \\
\hline $\begin{array}{l}\text { Ginsenoside } \\
\text { Rd }\end{array}$ & $\begin{array}{l}\text { Panax ginseng C. A. } \\
\text { Mey }\end{array}$ & $\begin{array}{l}\text { Tonifying Qi } \\
\text { herbs }\end{array}$ & NSCs & $\begin{array}{l}\text { Promote the } \\
\text { proliferation of NSCs }\end{array}$ & $\begin{array}{l}\text { Regulate the expression } \\
\text { of neurotrophic factor } 3 \\
\text { and activate the } \\
\text { expression of iNOS and } \\
\text { NMDA receptors }\end{array}$ & $\begin{array}{l}\text { In vivo } \\
\text { and in } \\
\text { vitro }\end{array}$ & {$[188]$} \\
\hline $\begin{array}{l}\text { Oleanolic } \\
\text { acid }\end{array}$ & Ligustrum lucidum Ait & $\begin{array}{l}\text { Tonifying } \\
\text { Yin herbs }\end{array}$ & $\begin{array}{l}\text { NSCs } \\
\text { and } \\
\text { NPCs }\end{array}$ & $\begin{array}{l}\text { Promote the self- } \\
\text { renewal and } \\
\text { differentiation of } \\
\text { NSCs; Promote the } \\
\text { neurogenesis in } \\
\text { hippocampus }\end{array}$ & $\begin{array}{l}\text { Increase the expression } \\
\text { of tubulin and the ratio } \\
\text { of tubulin /DAPI }\end{array}$ & $\begin{array}{l}\text { In vivo } \\
\text { and in } \\
\text { vitro }\end{array}$ & [24] \\
\hline $\begin{array}{l}\text { Stilbene } \\
\text { glucoside }\end{array}$ & $\begin{array}{l}\text { Fallopia multiflora } \\
\text { (Thunb.) Harald }\end{array}$ & $\begin{array}{l}\text { Tonifying } \\
\text { blood herbs }\end{array}$ & NSCs & $\begin{array}{l}\text { Promote the self- } \\
\text { renewal and } \\
\text { differentiation of } \\
\text { NSCs }\end{array}$ & $\begin{array}{l}\text { Increase the expression } \\
\text { of tubulin and the ratio } \\
\text { of tubulin /DAPI }\end{array}$ & In vitro & [24] \\
\hline Resveratrol & Fructus Mori & $\begin{array}{l}\text { Tonifying } \\
\text { Yin herbs }\end{array}$ & NSCs & $\begin{array}{l}\text { Promote the survival } \\
\text { and proliferation of } \\
\text { NSCs }\end{array}$ & $\begin{array}{l}\text { Up-regulate the } \\
\text { expression of Ptch-1, } \\
\text { Smo, Gli-1 protein and } \\
\text { RNA }\end{array}$ & In vitro & $\begin{array}{l}{[25,} \\
158]\end{array}$ \\
\hline $\begin{array}{l}(+)- \\
\text { Cholesten-3- } \\
\text { one }\end{array}$ & $\begin{array}{l}\text { Chinemys reevesii } \\
\text { (Gray) }\end{array}$ & $\begin{array}{l}\text { Tonifying } \\
\text { Yin herbs }\end{array}$ & NSCs & $\begin{array}{l}\text { Induce NSCs into } \\
\text { dopaminergic } \\
\text { neurons }\end{array}$ & $\begin{array}{l}\text { Activate BMP signal; } \\
\text { Improve the expression } \\
\text { of TH and BMPR-IB }\end{array}$ & In vitro & [189] \\
\hline Psoralen & Psoralea corylifolia L. & $\begin{array}{l}\text { Tonifying } \\
\text { kidney herbs }\end{array}$ & NSCs & $\begin{array}{l}\text { Increase the } \\
\text { expression of GFAP } \\
\text { protein in NSCs in } \\
\text { vitro }\end{array}$ & $\begin{array}{l}\text { Increase the expression } \\
\text { of GFAP protein }\end{array}$ & In vitro & {$[190]$} \\
\hline Icariin & $\begin{array}{l}\text { Epimediumgrandiflorum } \\
\text { Morr }\end{array}$ & $\begin{array}{l}\text { Tonifying } \\
\text { kidney herbs }\end{array}$ & NSCs & $\begin{array}{l}\text { Promote the self- } \\
\text { renewal and } \\
\text { differentiation of } \\
\text { NSCs }\end{array}$ & $\begin{array}{l}\text { Mediate the related } \\
\text { kinase signal } \\
\text { transduction pathways }\end{array}$ & In vitro & [191] \\
\hline $\begin{array}{l}\text { Salvianolic } \\
\text { acid B }\end{array}$ & Salvia miltiorrhiza Bge & $\begin{array}{l}\text { Huoxuehuayu } \\
\text { herbs }\end{array}$ & $\begin{array}{l}\text { NSCs } \\
\text { and } \\
\text { NSPCs }\end{array}$ & $\begin{array}{l}\text { Maintain the self- } \\
\text { renewal of } \\
\text { NSCs/NSPCs } \\
\text { Promote the } \\
\text { proliferation of NSCs }\end{array}$ & $\begin{array}{l}\text { Regulate PI3K/Akt } \\
\text { signaling pathway; } \\
\text { Improve the expression } \\
\text { of tau mRNA; Down- } \\
\text { regulate the expression } \\
\text { of mRNA GFAP }\end{array}$ & $\begin{array}{l}\text { In vivo } \\
\text { and in } \\
\text { vitro }\end{array}$ & $\begin{array}{l}{[192,} \\
193]\end{array}$ \\
\hline TMP & $\begin{array}{l}\text { Ligusticum wallichii } \\
\text { Franch }\end{array}$ & $\begin{array}{l}\text { Huoxuehuayu } \\
\text { herbs }\end{array}$ & NSCs & $\begin{array}{l}\text { Promote the } \\
\text { proliferation and } \\
\text { differentiation of } \\
\text { NSCs }\end{array}$ & $\begin{array}{l}\text { Increase the } \\
\text { phosphorylation of } \\
\text { erk } 1 / 2 ; \text { Reduce the } \\
\text { phosphorylation of p } 38\end{array}$ & In vitro & $\begin{array}{l}{[194,} \\
195]\end{array}$ \\
\hline PNS & $\begin{array}{l}\text { Panax Notoginseng } \\
\text { (Burk.) F.H. Chen }\end{array}$ & $\begin{array}{l}\text { Huoxuehuayu } \\
\text { herbs }\end{array}$ & NSCs & $\begin{array}{l}\text { Promote the self- } \\
\text { renewal, } \\
\text { proliferation, and } \\
\text { differentiation of } \\
\text { NSCs }\end{array}$ & $\begin{array}{l}\text { Improve the expression } \\
\text { of tuj-1, vimentin, and } \\
\text { nestin mRNA }\end{array}$ & In vitro & [196] \\
\hline Bilobalide & Ginkgo biloba & $\begin{array}{l}\text { Huoxuehuayu } \\
\text { herbs }\end{array}$ & NSCs & $\begin{array}{l}\text { Promote the } \\
\text { proliferation of NSCs }\end{array}$ & $\begin{array}{l}\text { Increase the } \\
\text { phosphorylation of } \\
\text { CREB and the level of } \\
\text { the neurotrophic factor }\end{array}$ & In vivo & [197] \\
\hline Berberine & Coptis chinensis Franch & $\begin{array}{l}\text { Qingrejiedu } \\
\text { herbs }\end{array}$ & NSCs & $\begin{array}{l}\text { Inhibit cell cycle } \\
\text { arrest } \\
\text { Promote the survival } \\
\text { and differentiation of } \\
\text { NSCs }\end{array}$ & $\begin{array}{l}\text { Improve the activity of } \\
\text { cell viability-dependent } \\
\text { NMDA }\end{array}$ & $\begin{array}{l}\text { In vivo } \\
\text { and in } \\
\text { vitro }\end{array}$ & [198] \\
\hline
\end{tabular}




\begin{tabular}{|c|c|c|c|c|c|c|c|}
\hline Baicalein & $\begin{array}{l}\text { Scutellaria baicalensis } \\
\text { Georgi }\end{array}$ & $\begin{array}{l}\text { Qingrejiedu } \\
\text { herbs }\end{array}$ & $\begin{array}{l}\text { NSCs } \\
\text { and } \\
\text { NPCs }\end{array}$ & $\begin{array}{l}\text { Promote the } \\
\text { differentiation of } \\
\text { NPCs into neurons; } \\
\text { Inhibit the apoptosis } \\
\text { and promote the } \\
\text { proliferation of NSCs }\end{array}$ & $\begin{array}{l}\text { Increase the expression } \\
\text { of presynaptic protein, } \\
\text { synapsin I, and PSD95 }\end{array}$ & In vivo & $\begin{array}{l}{[199,} \\
200]\end{array}$ \\
\hline Baicalin & $\begin{array}{l}\text { Scutellaria baicalensis } \\
\text { Georgi }\end{array}$ & $\begin{array}{l}\text { Qingrejiedu } \\
\text { herbs }\end{array}$ & $\begin{array}{l}\text { NSCs } \\
\text { and } \\
\text { NSPCs }\end{array}$ & $\begin{array}{l}\text { Determine the fate of } \\
\text { NSCs; Promote the } \\
\text { differentiation of } \\
\text { NSCs and NSPCs }\end{array}$ & $\begin{array}{l}\text { Reduce the expression } \\
\text { of p-STAT3 and Hes } 1 \text {; } \\
\text { Increase the expression } \\
\text { of NeuroD1 and Mash1; } \\
\text { Regulate the } \\
\text { expressionof p-stat } 3 \text { and } \\
\text { bHLH protein family }\end{array}$ & $\begin{array}{l}\text { In vivo } \\
\text { and in } \\
\text { vitro }\end{array}$ & $\begin{array}{l}{[201,} \\
202]\end{array}$ \\
\hline Paeoniflorin & $\begin{array}{l}\text { Paeonia lactiflora Pall, } \\
\text { Paeonia suffruticosa }\end{array}$ & $\begin{array}{l}\text { Qingrejiedu } \\
\text { herbs }\end{array}$ & $\begin{array}{l}\mathrm{NSCs} \\
\text { and } \\
\text { NSPCs }\end{array}$ & $\begin{array}{l}\text { Promote the } \\
\text { proliferation of nerve } \\
\text { cells and inhibit the } \\
\text { apoptosis of cells }\end{array}$ & $\begin{array}{l}\text { Activate the PI3k/Akt-1 } \\
\text { signaling pathway }\end{array}$ & In vitro & [203] \\
\hline
\end{tabular}

\subsection{BMP signaling pathway}

Bone morphogenetic protein (BMP) is a type of acidic peptide, and members of the transforming growth factor $\beta$ (TGF- $\beta$ ) superfamily $[163,164]$. BMP is an intercellular signal protein, and is important in the regulation of proliferation, differentiation, and apoptosis of NSCs [165, 166]. The sex-determining region Y-box2 (Sox2) and oligodendrocyte lineage transcription factor 2 (Olig2) are two target genes of the BMP pathway. Sox 2 is a highmobility group box transcription factor gene that can be expressed in the NSCs of SVZ and SGZ, and can also be expressed in the NPCs of VZ. Sox 2 can regulate the selfrenewal of NSCs and NPCs and prevent the apoptosis of NSCs [167-172]. Olig2 is a helix-loop-helix-transcription factor, mainly expressed in SVZ, and can promote the proliferation of NSPCs, induces the differentiation of NSCs into oligodendrocytes in vitro, and promotes the maturation of differentiated cells [173-175].

\section{Effects of TCM on NSCs proliferation and differentiation}

Numerous studies have shown that TCM has a regulatory effect on NSC proliferation and differentiation. TCM can improve the microenvironment, promote neurogenesis, repair nerve damage, and provide new treatments for cerebral injury and neurodegenerative diseases, such as Alzheimer's disease (AD), Parkinson's disease (PD), and strokes [176]. Here, we review the effects and underlying mechanisms of Chinese medicinal compouds, single herbs, and herb extract/the Chinese herbal monomer on NSCs proliferation and differentiation. Summarized are shownin Tables 3 and 4.

\subsection{Effects of compound Chinese medicinal preparation on NSCs proliferation and differentiation}

Experimental studies have found that compound Chinese medicine preparation has an important regulatory role on NSCs proliferation and differentiation. The compound prescriptions mainly include Huoxue Huayu (promoting blood circulation and removing blood stasis) and tonifying kidney recipes, of which Buyang Huanwu Decoction is a classic TCM prescription. This can promote blood circulation and dredge the meridians, and thus often used for the treatment of cerebrovascular disease. Buyang Huanwu is composed of Astragalus membranaceus (Fisch.) Bge (120 g), Angelica sinensis (Oilv.), Diells (10 g), Paeonia lactiflora Pall (10 g), Ligusticumwallichii Franch (10 g), Carthamus tinctorius L (10 g), Semen Persicae (10 g) and Flos carthami (4.5 g). Recent research has demonstrated that Buyang Huanwu Decoction can promote the proliferation and differentiation of NSCs, and improve the expression of growth-associated protein-43 (GAP-43) [177]. It can also promote the differentiation of neuroepithelial stem cells into neurons and astrocytes [178], the growth of nerve cells and nerve fibers, and the growth and differentiation of NSPCs. Experimental results have demonstrated that the content of $\mathrm{Ca}_{2}{ }^{+}$significantly decreased and expression of neurofilament (NF) and glial fibrillary acidic protein (GFAP) significantly increased in the NSPCs treated with Buyang Huanwu Decoction [179].

Jiaweisinisan consists of Stellaria dichotoma L. var. lanceolata Bge, Paeonia lactiflora Pall, Citrus reticulata Banco, Poncirus trifoliate (L.) Raf, Lycium barbarum L, 
Gardenia jasminoides Ellis, Radix Rehmanniae, and Abalone. These are weighed according to the ratio of 1:3:1:3:1:4:6, respectively. This Jiaweisinisan prescription can also promote the proliferation of hippocampal NPCs, and inhibit the apoptosis of glial cells and neurons differentiated from Hippocampal-NPCs [180].

Shengyu decoction, a traditional Chinese medicine, has been used to treat diseases that involve a deficit in "qi" and "blood." Modified Shengyu decoction (MSD) was designed to treat brain injury after head trauma, according to traditional Chinese medicine theories, and is based on the traditional Shengyu. Four additional herbs are in the MSD: Salvia mil-tiorrhiza Bunge, Commiphora myrrha (Nees) Engl., Acorus calamus L, and Curcuma aromatica Salisb. A study on the treatment of traumatic injury in rats using the Shengyu decoction showed that it could increase the expression of nerve growth factor (NGF), glial cell line-derived neurotrophic factor (GDNF), neural cell adhesion molecule (NCAM), and Tenascin-C (TN-C) in the cortex and hippocampus of rats. It can also inhibit the expression of Nogo-A and promote the proliferation of NSCs/NSPCs and their differentiation into neurons [181].

Fuzhisan is a traditional Chinese medicine prescription, composed mainly of four Chinese medicinal herbs: Panax ginseng C. A. Mey, Scutellaria baicalensis Georgi, Acorus gramineus Soland, and Glycyrrhiza uralensis Fisch. Experimental studies have shown that Fuzhisan can promote the proliferation of NSPCs and improve the survival rate of newborn cells [182].

Xiehuo Bushen Decoction consists of Rheum officinale baill, Paeonia suffruticosa Andr, Paeonia lactiflora Pall, Astragalus membranaceus (Fisch.) Bge, Cuscuta Lam, Viscum coloratum (Kom.), and Nakai. It can promote the survival and differentiation of NSCs transplanted into a brain after cerebral hemorrhage. The possible mechanism is that the Xiehuo Bushen Decoction can enhance the expression of interleukin 4 (IL-4) mRNA and down-regulate the expression of interferon-gamma (IFN-gama) mRNA [27].

Polygonummultiflorum Thunberg complex composition-12 (PMC-12), a mixture of four medicinal herbs, includes Polygonum multiflorum Thunb, Radix Polygalae, Rehmannia glutinosa, and Acorus gramineus Soland. PMC-12 was found to promote the proliferation of NSPCs in the hippocampus, increase the survival rate of newborn neurons, and encourage neurogenesis in the hippocampus [183].

Although compounds of Chinese medicine have been found to regulate the proliferation and differentiation of NSCs through experiments, it has not been determined whether one or a combination of the active ingredients influences the proliferation and differentiation of the NSCs, because of the complexity of the active ingredients of the compounds of Chinese medicine. Further experiments are therefore required to establish this.

\subsection{Effect of single herbs on NSCs proliferation and differentiation}

Extensive research has been conducted on Chinese herbs, such as those used for Huoxuehuayu and Qingrejiedu (clearing away heat and toxic material) in the study of NSC proliferation and differentiation.

Salvia miltiorrhiza Bge is a common traditional Chinese herb for Huoxuehuayu. It has anti-oxidation and anti-inflammatory functions and is often used to treat nervous system diseases. Studies have shown that Danshen can increase the expression of the nestin significantly, promote the differentiation of induced multifunctional NSCs into neurons in vitro, and promote the survival and differentiation of NSCs derived from multifunctional stem cells [22]. Another commonly used herb for Huoxuehuayu, Sambucus williamsii Hance, was also shown in in vitro experiments to promote the proliferation of NSCs, but the study was conducted together with the herbs of Qingrejiedu [184].

The herbal preparation composed of Scutellariacalensis Georgi, Phellodendron chinense Schneid, and Ligusticumwallichii Franch has been shown to promote the proliferation of NSCs in vitro. In vitro study shows that this herbal medicine can improve the symptoms of depression in mice models, which was mainly achieved through the machanism of increasing the content of corticosterone and promoting hippocampal precursor cell proliferation [23].

Experiments also showed that the traditional Chinese herb Sambucus williamsii Hance can promote the differentiation of induced pluripotent stem cells (iPSCs) into neurons by up-regulating the expression of tubulin-1 (Tuj1) and nestin, and down-regulating the expression of Oct4 and Sox2 [184].

\subsection{Effects of Chinese herbal monomer on NSCs proliferation and differentiation}

In recent years, numerous experiments have demonstrated that the extract of Chinese herbal monomer Plays a specific regulatory role in NSC proliferation and differentiation. The current research mainly focuses on the extraction of effective components from the Chinese tonifying herbs HuoxueHuayu and QingreJiedu (Fig.1). 


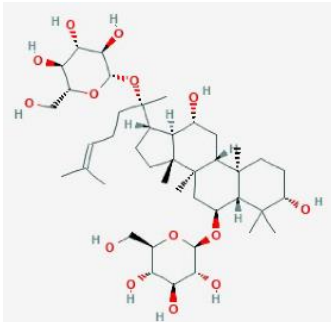

Ginsenoside Rg1

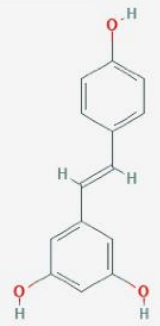

Psoralen

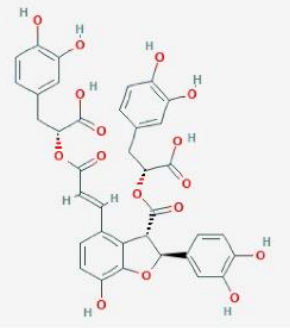

Salvianolic acid B

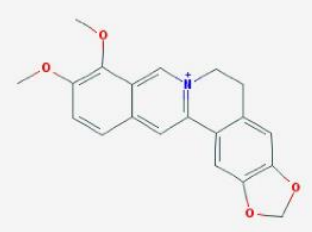

Berberine

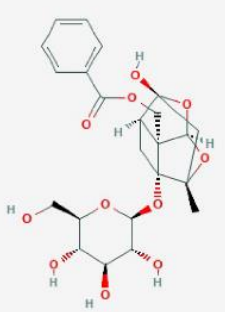

Paeoniflorin

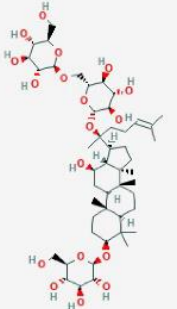

Ginsenoside Rd

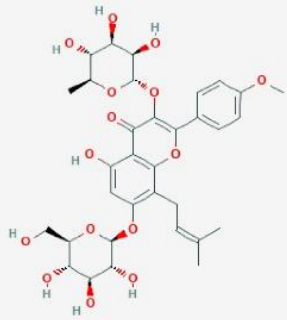

Resveratrol

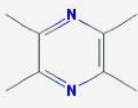

TMP

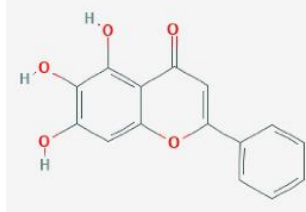

Baicalein

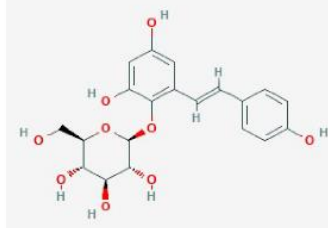

Stilbene glucoside

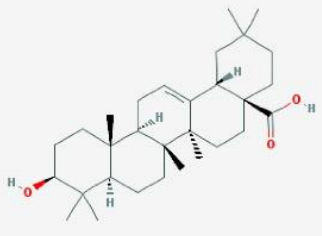

Oleanolic acid

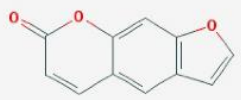

Icariin

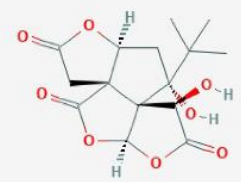

Bilobalide

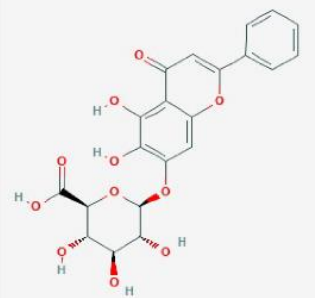

Baicalin

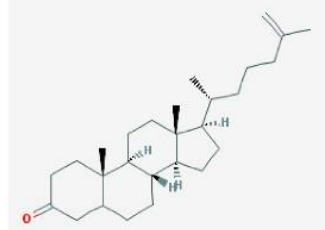

(+)-Cholesten-3-one

Figure 1. Structures of Chinese herbal monomers 


\subsubsection{Monomers from Chinese herbs}

\subsubsection{Tonifying Qi herbs}

Panax ginseng C. A. Mey is an herb used in TCM for tonifying "Qi". Recent research has shown that it has roles in anti-anxiety, anti-depression, and cognitive functionenhancing, among others. The numerous active ingredients in Panax ginseng C. A. Mey have the effect of nerve protection [185]. Ginsenoside $\mathrm{Rg} 1$ can promote the differentiation of NSCs into neurons and play a neuroprotective role by increasing the expression of SOX2 and decreasing the expression of interleukin $1 \beta$ (IL-1 $1 \beta$ ), interleukin 6 (IL-6), and TNF-a. The differentiation of NSCs can be promoted by cAMP protein kinase A (PKA) and PI3K-Akt signaling pathway [186, 187]. Ginsenoside $\mathrm{Rd}$ can promote the proliferation of NSCs by regulating the expression of neurotrophic factor 3 and activating the expression of inducible nitric oxide synthase (iNOS) and N-methyl-D-aspartic acid (NMDA) receptors [188].

\subsubsection{Tonifying Yin herbs}

Oleanolic acid extracted from the "Yin"-tonifying Chinese herbal Ligustrum lucidum Ait and stilbene glycoside extracted from Fallopia multiflora (Thunb.) Harald have been found to promote the self-renewal and differentiation of NSCs in vitro. The relevant mechanism may be the increase of the expression of tubulin and the ratio of tubulin/DAPI [24].

Resveratrol is a polyphenolic compound found in various plants, and is an effective component of the Chinese herb Fructus Mori. Experiments have established that it can promote the survival and proliferation of NSCs. In addition, the expression of Patched-1 (Ptch-1), Smoothened (Smo), Gli-1 protein, and RNA were all upregulated in resveratrol-treated NSCs [25, 158].

The tortoiseshell cholesterol extracted from Chinemys reevesii (Gray), (+)-Cholesten-3-one, can induce NSCs into dopaminergic neurons through a bone morphogenetic protein (BMP) signal, thus providing a possible new treatment for PD [189].

\subsubsection{Tonifying kidney herbs}

Psoralen is an effective component extracted from the Chinese herb (Psoralea corylifolia L.), and is representative of kidney-tonifying herbs. Psoralen has been found to increase the expression of glial fibrillary acidic protein (GFAP) in NSCs in vitro, thereby promoting the differentiation of NSCs into astrocytes [190]. Icariin, the extract of Epimediumgrandiflorum Morr, which is another well-known Chinese herb for kidney tonifying, can promote self-renewal and differentiation in NSCs. This can be mediated by the related kinase signal transduction pathways [191].

\subsubsection{Huoxuehuayu herbs}

Salvianolic acid B is the root and rhizome of Salvia miltiorrhiza Bge, a traditional Chinese herb of HuoXueHuaYu. It can maintain the self-renewal of NSCs/ progenitor cells and promote the proliferation of NSCs though the regulation of the PI3K/Akt signaling pathway [192]. It also promotes the growth of the synapses of NSCs and the differentiation of neurons [193].

Tamethylpyrazine extracted from Ligusticum wallichii Franch can promote the proliferation and differentiation of NSCs under the condition of hypoxia in vitro [194], and also promotes the differentiation of NSCs after cerebral ischemia [195].

Panax notoginseng saponins (PNS), which has the effect of Huoxuehuayu, simultaneously promotes the expression of nestin/BrdU, improves the expression of tubulin-1 (tuj1), vimentin, and Nestin mRNA, and promote the self-renewal, proliferation, and differentiation of NSCs [196].

Bilobalide extracted from Ginkgo biloba can increase the phosphorylation of the Cyclic AMP response element binding protein (CREB) in NSCs and the level of the neurotrophic factor, and promote the proliferation of NSCs [197].

\subsubsection{Qingrejiedu herbs}

Berberine is the main active ingredient of Coptis chinensis Franch, a traditional Chinese herb of Qingrejiedu. Studies show that it can inhibit cell cycle arrest and promote the survival and differentiation of NSCs [198]. Baicalein and baicalin are the two main active components of Scutellaria baicalensis Georgi, and baicalein can promote the differentiation of NPCs into neurons. The mechanism may be related to the increase of the expression of presynaptic protein, synapsin I and postsynaptic density proteins 95 (PSD95) [199]. Baicalein can also inhibit apoptosis and promote the differentiation of NSCs [200]. Baicalin, another extract, can determine the fate of NSCs, and promote neurogenesis [201]. It also can regulate the expression of phosphorylated signal transducer transcription3 (p-stat3) and bHLH family proteins, subsequently promoting the differentiation of NSCs/NSPCs [202].

Paeoniflorin is a natural compound extracted from the roots of the Chinese herbs Paeonia lactiflora Pall and Paeonia suffruticosa. It can promote the proliferation and survival of NSCs and precursor cells in vitro and inhibit 
the apoptosis of cells. The mechanism may be related to down-regulation of the expression of inhibitor $\mathrm{Kb}(\mathrm{i \kappa B})$, nuclear transcription factor- $\mathrm{\kappa B}(\mathrm{NF}-\mathrm{\kappa} B)$, and interleukin$1 \beta$ (IL-1 $\beta$ )[203].

As mentioned above, the natural compounds extracted from traditional Chinese medicine, which play a regulatory role in the proliferation and differentiation of NSCs, can be divided into the three categories of tonifying (for tonifying Qi, Yin, and kidney), Huoxuehuayu, and Qingrejiedu herbs. The effects of tonifying herbs on NSCs proliferation and differentiation have been studied most. In the theory of TCM, the nerve function damage is often due to kidney deficiency caused by the deficiency of the marrow-reservoir. These tonifying herbs are therefore often used for the treatment of nervous system diseases. In addition, kidney essence is also believed to be critical in maintaining a variety of life activities. The potential function of various organs can be stimulated through the method of tonifying the kidneys, which is interlinked with the method of promoting the proliferation and differentiation of NSCs to repair brain neurons in the treatment of brain damage and neurodegenerative diseases. In addition, the insufficient cerebral blood supply caused by cerebral arteriosclerosis or atherosclerotic plaque inflammatory response is also a common cause of nervous system diseases. Therefore, the heat detoxification practice of TCM is also often applied to treat nervous system diseases, including the clinical use of Huoxuehuayu and Qingrejiedu herbs. Experimental studies also demonstrate that Chinese herbs and their active ingredients can regulate the proliferation and differentiation of NSCs, which provides a broader space for discovering drugs that can regulate the proliferation and differentiation of NSCs.

\section{Summary and Perspectives}

NSCs pass through the different stages of NSPCs, NPCs, and neuroblasts in the process of proliferation and differentiation into neural cell lineage, and their corresponding markers are found at different stages. In the process of neurogenesis, and in NSC proliferation and differentiation, a variety of internal and external factors precisely regulate NSCs through different protein pathways. Studies have found that single herbs, herb extracts/Chinese herbal monomers, and compounds of Chinese medicine have a certain regulatory role on the proliferation and differentiation of NSCs. However, most of the current studies focus on single pathways. However, the regulation of the NSC proliferation and differentiation is involved in a complex signal network. In addition, NSC research into TCM lacks multi-targeted and multi-channel approaches, which is a systematic deficiency and thus they cannot fully explain the detailed mechanisms underlying regulating NSC by TCM. The effects of TCM promoting neurogenesis are still in the experimental stage, and may not be ready for the clinical application. In short, TCM should be played to its advantages, and in combination with modern medicine used to explore its potential in the regulation of neurogenesis to provide new possibilities for the treatment of brain damage and neurodegenerative diseases.

\section{Acknowledgements}

The work is supported by the Guiding Project of Fujian Science and Technology (Grant: 2017Y0053), and the Traditional Chinese Medicine Research Project (Grant: 2017FJZYLC501).

\section{References}

[1] Bond AM, Bhalala OG, Kessler JA (2012). The dynamic role of bone morphogenetic proteins in neural stem cell fate and maturation. Dev Neurobiol, 72: 1068-1084.

[2] Ming GL, Song H (2011). Adult neurogenesis in the mammalian brain: significant answers and significant questions. Neuron, 70: 687-702.

[3] Bamba Y, Shofuda T, Kanematsu D, Nonaka M, Yamasaki M, Okano H, et al. (2014). Differentiation, polarization, and migration of human induced pluripotent stem cell-derived neural progenitor cells co-cultured with a human glial cell line with radial glial-like characteristics. Biochem Biophys Res Commun, 447: 683-688.

[4] Cheng F, Lu XC, Hao HY, Dai XL, Qian TD, Huang BS, et al. (2014). Neurogenin 2 converts mesenchymal stem cells into a neural precursor fate and improves functional recovery after experimental stroke. Cell Physiol Biochem, 33: 847-858.

[5] Kozhich OA, Hamilton RS, Mallon BS (2013). Standardized generation and differentiation of neural precursor cells from human pluripotent stem cells. Stem Cell Rev, 9: 531-536.

[6] Panman L, Andersson E, Alekseenko Z, Hedlund E, Kee N, Mong J, et al. (2011). Transcription factorinduced lineage selection of stem-cell-derived neural progenitor cells. Cell Stem Cell, 8: 663-675.

[7] Zhao X, Wu J, Zheng M, Gao F, Ju G (2012). Specification and maintenance of oligodendrocyte precursor cells from neural progenitor cells: involvement of microRNA-7a. Mol Biol Cell, 23: 2867-2878.

[8] Haiyan H, Rensong Y, Guoqin J, Xueli Z, Huaying $X$, Yanwu X (2016). Effect of Astragaloside IV on Neural Stem Cell Transplantation in Alzheimer's Disease Rat Models. Evid Based Complement 
Alternat Med, 2016: 3106980.

[9] Li XY, Bao XJ, Wang RZ (2015). Potential of neural stem cell-based therapies for Alzheimer's disease. J Neurosci Res, 93: 1313-1324.

[10] Liu Y, Liu K, Qin W, Liu C, Zheng X, Deng Y, et al. (2016). Effects of stem cell therapy on protein profile of parkinsonian rats using an (18) O-labeling quantitative proteomic approach. Proteomics, 16: 1023-1032.

[11] Song YY, Peng CG, Ye XB (2015). Combination of edaravone and neural stem cell transplantation repairs injured spinal cord in rats. Genet Mol Res, 14: 19136-19143.

[12] Ring KL, An MC, Zhang N, O'Brien RN, Ramos EM, Gao F, et al. (2015). Genomic Analysis Reveals Disruption of Striatal Neuronal Development and Therapeutic Targets in Human Huntington's Disease Neural Stem Cells. Stem Cell Reports, 5: 1023-1038.

[13] Hefferan MP, Galik J, Kakinohana O, Sekerkova G, Santucci C, Marsala S, et al. (2012). Human neural stem cell replacement therapy for amyotrophic lateral sclerosis by spinal transplantation. PLoS One, 7: e42614.

[14] Lee-Kubli CA, Lu P (2015). Induced pluripotent stem cell-derived neural stem cell therapies for spinal cord injury. Neural Regen Res, 10: 10-16.

[15] Xue YZ, Li XX, Li L, Pang SL, Yao JG, Hao PL (2014). Curative effect and safety of intrathecal transplantation of neural stem cells for the treatment of cerebral hemorrhage. Genet Mol Res, 13: 82948300.

[16] Zhang T, Yang QW, Wang SN, Wang JZ, Wang Q, Wang Y, et al. (2010). Hyperbaric oxygen therapy improves neurogenesis and brain blood supply in piriform cortex in rats with vascular dementia. Brain Inj, 24: 1350-1357.

[17] Suksuphew S, Noisa P (2015). Neural stem cells could serve as a therapeutic material for age-related neurodegenerative diseases. World J Stem Cells, 7: 502-511.

[18] Liu Z, Guo F, Wang Y, Li C, Zhang X, Li H, et al. (2016). BATMAN-TCM: a Bioinformatics Analysis Tool for Molecular mechANism of Traditional Chinese Medicine. Sci Rep, 6: 21146.

[19] Li L, Zhang L, Yang CC (2016). Multi-Target Strategy and Experimental Studies of Traditional Chinese Medicine for Alzheimer's Disease Therapy. Curr Top Med Chem, 16: 537-548.

[20] Huang L, Lv Q, Liu F, Shi T, Wen C (2015). A Systems Biology-Based Investigation into the Pharmacological Mechanisms of Sheng-ma-bie-jiatang Acting on Systemic Lupus Erythematosus by Multi-Level Data Integration. Sci Rep, 5: 16401.

[21] Li X, Wu L, Liu W, Jin Y, Chen Q, Wang L, et al. (2014). A network pharmacology study of Chinese medicine QiShenYiQi to reveal its underlying multi- compound, multi-target, multi-pathway mode of action. PLoS One, 9: e95004.

[22] Shu T, Pang M, Rong L, Zhou W, Wang J, Liu C, et al. (2014). Effects of Salvia miltiorrhiza on neural differentiation of induced pluripotent stem cells. J Ethnopharmacol, 153: 233-241.

[23] Pao LH, Lu SW, Sun GG, Chiou SH, Ma KH (2012). Three Chinese herbal medicines promote neuroproliferation in vitro, and reverse the effects of chronic mild stress on behavior, the HPA axis, and proliferation of hippocampal precursor cell in vivo. $\mathrm{J}$ Ethnopharmacol, 144: 261-269.

[24] Zhang YL, Zhang LL, Song WS, Han WW, Huang JH, Zhou Z (2014). Effective Components of three kinds of shen-supplementing Chinese medicine on self-renewal and neuron-like differentiation of NSCs in $\mathrm{AD}$ mouse embryos: an experimental research. Zhongguo Zhong Xi Yi Jie He Za Zhi, 34: 12451249.

[25] Torres-Perez M, Tellez-Ballesteros RI, Ortiz-Lopez L, Ichwan M, Vega-Rivera NM, Castro-Garcia M, et al. (2015). Resveratrol Enhances Neuroplastic Changes, Including Hippocampal Neurogenesis, and Memory in Balb/C Mice at Six Months of Age. PLoS One, 10: e145687.

[26] Ren ZL, Zuo PP (2012). Neural regeneration: role of traditional Chinese medicine in neurological diseases treatment. J Pharmacol Sci, 120: 139-145.

[27] Zhong PC, Li XQ, Liang QH, Luo WF, Liu QE, Luo JK, et al. (2008). Effects of Xiehuo Bushen Decoction on survival and differentiation of transplanted neural stem cells in brains of rats with intracerebral hemorrhage. Zhong Xi Yi Jie He Xue Bao, 6: 626-631.

[28] Jia S, Mou C, Ma Y, Han R, Li X (2016). Magnesium regulates neural stem cell proliferation in the mouse hippocampus by altering mitochondrial function. Cell Biol Int, 40: 465-471.

[29] Hsueh YY, Chang YJ, Huang CW, Handayani F, Chiang YL, Fan SC, et al. (2015). Synergy of endothelial and neural progenitor cells from adiposederived stem cells to preserve neurovascular structures in rat hypoxic-ischemic brain injury. Sci Rep, 5: 14985.

[30] Maggi R, Zasso J, Conti L (2014). Neurodevelopmental origin and adult neurogenesis of the neuroendocrine hypothalamus. Front Cell Neurosci, 8: 440.

[31] Doetsch F, Garcia-Verdugo JM, Alvarez-Buylla A (1997). Cellular composition and three-dimensional organization of the subventricular germinal zone in the adult mammalian brain. J Neurosci, 17: 50465061 .

[32] Achanta P, Capilla-Gonzalez V, Purger D, Reyes J, Sailor K, Song H, et al. (2012). Subventricular zone localized irradiation affects the generation of 
proliferating neural precursor cells and the migration of neuroblasts. Stem Cells, 30: 2548-2560.

[33] Lendahl U, Zimmerman LB, McKay RD (1990). CNS stem cells express a new class of intermediate filament protein. Cell, 60: 585-595.

[34] Park DM, Jung J, Masjkur J, Makrogkikas S, Ebermann D, Saha S, et al. (2013). Hes3 regulates cell number in cultures from glioblastoma multiforme with stem cell characteristics. Sci Rep, 3: 1095.

[35] Kageyama R, Ohtsuka T, Hatakeyama J, Ohsawa R (2005). Roles of bHLH genes in neural stem cell differentiation. Exp Cell Res, 306: 343-348.

[36] Lai YJ, Li MY, Yang CY, Huang KH, Tsai JC, Wang TW (2014). TRIP6 regulates neural stem cell maintenance in the postnatal mammalian subventricular zone. Dev Dyn, 243: 1130-1142.

[37] Ikeda Y, Ikeda MA (2015). Cyclin E marks quiescent neural stem cells and caspase-3-positive newborn cells during adult hippocampal neurogenesis in mice. Neurosci Lett, 607: 90-96.

[38] Stelzer S, Worlitzer MM, Bahnassawy L, Hemmer K, Rugani K, Werthschulte I, et al. (2012). JAM-C is an apical surface marker for neural stem cells. Stem Cells Dev, 21: 757-766.

[39] Kaneko J, Kinoshita MO, Machida T, Shinoda Y, Nagatsuka Y, Hirabayashi Y (2011). Phosphatidylglucoside: a novel marker for adult neural stem cells. J Neurochem, 116: 840-844.

[40] Klassen H, Schwartz MR, Bailey AH, Young MJ (2001). Surface markers expressed by multipotent human and mouse neural progenitor cells include tetraspanins and non-protein epitopes. Neurosci Lett, 312: $180-182$.

[41] Huang CL, Liu D, Masuya D, Kameyama K, Nakashima T, Yokomise H, et al. (2004). MRP1/CD9 gene transduction downregulates Wnt signal pathways. Oncogene, 23: 7475-7483.

[42] Chaubey S, Wolfe JH (2013). Transplantation of CD15-enriched murine neural stem cells increases total engraftment and shifts differentiation toward the oligodendrocyte lineage. Stem Cells Transl Med, 2: 444-454.

[43] Tejera E, Rocha-Perugini V, Lopez-Martin S, PerezHernandez D, Bachir AI, Horwitz AR, et al (2013). CD81 regulates cell migration through its association with Rac GTPase. Mol Biol Cell, 24: 261-273.

[44] Patro N, Naik A, Patro IK (2015). Differential temporal expression of S100beta in developing rat brain. Front Cell Neurosci, 9: 87.

[45] Baghbaderani BA, Behie LA, Mukhida K, Hong M, Mendez I (2011). New bioengineering insights into human neural precursor cell expansion in culture. Biotechnol Prog, 27: 776-787.

[46] Haus DL, Nguyen HX, Gold EM, Kamei N, Perez H, Moore HD, et al. (2014). CD133-enriched Xeno-
Free human embryonic-derived neural stem cells expand rapidly in culture and do not form teratomas in immunodeficient mice. Stem Cell Res, 13: 214226.

[47] Tingling JD, Bake S, Holgate R, Rawlings J, Nagsuk PP, Chandrasekharan J, et al. (2013). CD24 expression identifies teratogen-sensitive fetal neural stem cell subpopulations: evidence from developmental ethanol exposure and orthotopic cell transfer models. PLoS One, 8: e69560.

[48] Kim BJ, Lee YA, Kim KJ, Kim YH, Jung MS, Ha SJ, et al. (2015). Effects of paracrine factors on CD24 expression and neural differentiation of male germline stem cells. Int J Mol Med, 36: 255-262.

[49] Vinci L, Ravarino A, Fanos V, Naccarato AG, Senes G, Gerosa C, et al. (2016). Immunohistochemical markers of neural progenitor cells in the early embryonic human cerebral cortex. Eur J Histochem, 60: 2563.

[50] Wang H, Xu H, Niu J, Mei F, Li X, Kong J, et al. (2010). Haloperidol activates quiescent oligodendroglia precursor cells in the adult mouse brain. Schizophr Res, 119: 164-174.

[51] Biname F, Sakry D, Dimou L, Jolivel V, Trotter J (2013). NG2 regulates directional migration of oligodendrocyte precursor cells via Rho GTPases and polarity complex proteins. J Neurosci, 33: 10858-10874.

[52] Lendahl U, Zimmerman LB, McKay RD (1990). CNS stem cells express a new class of intermediate filament protein. Cell, 60: 585-595.

[53] Campbell JG, Miller DC, Cundiff DD, Feng Q, Litofsky NS (2015). Neural stem/progenitor cells react to non-glial cns neoplasms. Springerplus, 4: 53.

[54] Michalczyk K, Ziman M (2005). Nestin structure and predicted function in cellular cytoskeletal organisation. Histol Histopathol, 20: 665-671.

[55] Ernst C, Christie BR (2006). The putative neural stem cell marker, nestin, is expressed in heterogeneous cell types in the adult rat neocortex. Neuroscience, 138: 183-188.

[56] Campbell JG, Miller DC, Cundiff DD, Feng Q, Litofsky NS (2015). Neural stem/progenitor cells react to non-glial cns neoplasms. Springerplus, 4: 53.

[57] Kaneko Y, Sakakibara S, Imai T, Suzuki A, Nakamura Y, Sawamoto K, et al. (2000). Musashi1: an evolutionally conserved marker for CNS progenitor cells including neural stem cells. Dev Neurosci, 22: 139-153.

[58] Cambuli FM, Correa BR, Rezza A, Burns SC, Qiao M, Uren PJ, et al. (2015). A Mouse Model of Targeted Musashi1 Expression in Whole Intestinal Epithelium Suggests Regulatory Roles in Cell Cycle and Stemness. Stem Cells, 33: 3621-3634.

[59] Kanemura Y, Mori K, Sakakibara S, Fujikawa H, Hayashi H, Nakano A, et al. (2001). Musashi1, an 
evolutionarily conserved neural RNA-binding protein, is a versatile marker of human glioma cells in determining their cellular origin, malignancy, and proliferative activity. Differentiation, 68: 141-152.

[60] Okano H, Imai T, Okabe M (2002). Musashi: a translational regulator of cell fate. J Cell Sci, 115: 1355-1359.

[61] Kawase S, Kuwako K, Imai T, Renault-Mihara F, Yaguchi K, Itohara S, et al. (2014). Regulatory factor $\mathrm{X}$ transcription factors control Musashi1 transcription in mouse neural stem/progenitor cells. Stem Cells Dev, 23: 2250-2261.

[62] Nakamura Y, Yamamoto M, Oda E, Yamamoto A, Kanemura Y, Hara M, et al. (2003). Expression of tubulin beta II in neural stem/progenitor cells and radial fibers during human fetal brain development. Lab Invest, 83: 479-489.

[63] Sugita Y, Nakamura Y, Yamamoto M, Oda E, Tokunaga O, Shigemori M (2005). Expression of tubulin beta II in neuroepithelial tumors: reflection of architectural changes in the developing human brain. Acta Neuropathol, 110: 127-134.

[64] Hernandez PP, Olivari FA, Sarrazin AF, Sandoval PC, Allende ML (2007). Regeneration in zebrafish lateral line neuromasts: expression of the neural progenitor cell marker sox 2 and proliferationdependent and-independent mechanisms of hair cell renewal. Dev Neurobiol, 67: 637-654.

[65] Bani-Yaghoub M, Tremblay RG, Lei JX, Zhang D, Zurakowski B, Sandhu JK, et al. (2006). Role of Sox 2 in the development of the mouse neocortex. Dev Biol, 295: 52-66.

[66] Feng N, Han Q, Li J, Wang S, Li H, Yao X, et al. (2014). Generation of highly purified neural stem cells from human adipose-derived mesenchymal stem cells by Sox1 activation. Stem Cells Dev, 23: 515-529.

[67] Venere M, Han YG, Bell R, Song JS, Alvarez-Buylla A, Blelloch R (2012). Sox1 marks an activated neural stem/progenitor cell in the hippocampus. Development, 139: 3938-3949.

[68] Asadi S, Dehghan S, Hajikaram M, Mowla SJ, Ahmadiani AA, Javan M (2015). Comparing The Effects of Small Molecules BIX-01294, Bay K8644, RG-108 and Valproic Acid, and Their Different Combinations on Induction of Pluripotency MarkerGenes by Oct4 in The Mouse Brain. Cell J, 16: 416425.

[69] Xie Y, Li X, Zhang X, Mei S, Li H, Urso A, et al. (2014). The Drosophila Sp8 transcription factor Buttonhead prevents premature differentiation of intermediate neural progenitors. eLife, 3 .

[70] Zhang XM, Cai Y, Wang F, Wu J, Mo L, Zhang F, et al. (2016). Sp8 expression in putative neural progenitor cells in guinea pig and human cerebrum. Dev Neurobiol, 76: 939-955.
[71]

Yamada J, Jinno S (2014). S100A6 (calcyclin) is a novel marker of neural stem cells and astrocyte precursors in the subgranular zone of the adult mouse hippocampus. Hippocampus, 24: 89-101.

[72] Holzmann J, Hennchen M, Rohrer H (2015). Prox1 identifies proliferating neuroblasts and nascent neurons during neurogenesis in sympathetic ganglia. Dev Neurobiol, 75: 1352-1367.

[73] Stergiopoulos A, Elkouris M, Politis PK (2014). Prospero-related homeobox 1 (Prox1) at the crossroads of diverse pathways during adult neural fate specification. Front Cell Neurosci, 8: 454.

[74] Magro G, Salvatorelli L, Cataldo AD, Musumeci G, Spoto G, Parenti R (2015). Cyclin D1 in human neuroblastic tumors recapitulates its developmental expression: An immunohistochemical study. Acta Histochem, 117: 415-424.

[75] Yang SL, Yang M, Herrlinger S, Liang C, Lai F, Chen JF (2015). MiR-302/367 regulate neural progenitor proliferation, differentiation timing, and survival in neurulation. Dev Biol, 408: 140-150.

[76] Yang HK, Sundholm-Peters NL, Goings GE, Walker AS, Hyland K, Szele FG (2004). Distribution of doublecortin expressing cells near the lateral ventricles in the adult mouse brain. J Neurosci Res, 76: 282-295.

[77] Walker TL, Yasuda T, Adams DJ, Bartlett PF (2007). The doublecortin-expressing population in the developing and adult brain contains multipotential precursors in addition to neuronal-lineage cells. J Neurosci, 27: 3734-3742.

[78] Morgan TH (1917). The Theory of the Gene. The American Naturalist, 51: 513-544.

[79] Grandbarbe L, Bouissac J, Rand M, Hrabe DAM, Artavanis-Tsakonas S, Mohier E (2003). DeltaNotch signaling controls the generation of neurons/glia from neural stem cells in a stepwise process. Development, 130: 1391-1402.

[80] Hitoshi S, Alexson T, Tropepe V, Donoviel D, Elia AJ, Nye JS, et al. (2002). Notch pathway molecules are essential for the maintenance, but not the generation, of mammalian neural stem cells. Genes Dev, 16: 846-858.

[81] Kunisato A, Chiba S, Nakagami-Yamaguchi E, Kumano K, Saito T, Masuda S, et al. (2003). HES-1 preserves purified hematopoietic stem cells ex vivo and accumulates side population cells in vivo. Blood, 101: 1777-1783.

[82] Ohtsuka T, Sakamoto M, Guillemot F, Kageyama R (2001). Roles of the basic helix-loop-helix genes Hes 1 and Hes5 in expansion of neural stem cells of the developing brain. J Biol Chem, 276: 3046730474.

[83] Kabos P, Kabosova A, Neuman T (2002). Blocking HES1 expression initiates GABAergic differentiation and induces the expression of $\mathrm{p} 21$ 
(CIP1/WAF1) in human neural stem cells. J Biol Chem, 277: 8763-8766.

[84] Nakamura Y, Sakakibara S, Miyata T, Ogawa M, Shimazaki T, Weiss S, et al. (2000). The bHLH gene hes 1 as a repressor of the neuronal commitment of CNS stem cells. J Neurosci, 20: 283-293.

[85] Chen J, Zacharek A, Li A, Cui X, Roberts C, Lu M, et al. (2008). Atorvastatin promotes presenilin-1 expression and Notch1 activity and increases neural progenitor cell proliferation after stroke. Stroke, 39: 220-226.

[86] Li D, Takeda N, Jain R, Manderfield LJ, Liu F, Li L, et al. (2015). Hopx distinguishes hippocampal from lateral ventricle neural stem cells. Stem Cell Res, 15: 522-529.

[87] Zhang Z, Gao F, Kang X, Li J, Zhang L, Dong W, et al. (2015). Exploring the potential relationship between Notch pathway genes expression and their promoter methylation in mice hippocampal neurogenesis. Brain Res Bull, 113: 8-16.

[88] Ongaro A, Pellati A, Bagheri L, Rizzo P, Caliceti C, Massari L, et al. (2016). Characterization of Notch Signaling During Osteogenic Differentiation in Human Osteosarcoma Cell Line MG63. J Cell Physiol, 231: 2652-2663.

[89] Wang J, Ye Z, Zheng S, Chen L, Wan Y, Deng Y, et al. (2016). Lingo-1 shRNA and Notch signaling inhibitor DAPT promote differentiation of neural stem/progenitor cells into neurons. Brain Res, 1634: 34-44.

[90] Goto M, Hojo M, Ando M, Kita A, Kitagawa M, Ohtsuka T, et al. (2015). Hes1 and Hes5 are required for differentiation of pituicytes and formation of the neurohypophysis in pituitary development. Brain Res, 1625: 206-217.

[91] Mendes-da-Silva C, Lemes SF, Baliani TS, Versutti MD, Torsoni MA (2015). Increased expression of Hes5 protein in Notch signaling pathway in the hippocampus of mice offspring of dams fed a highfat diet during pregnancy and suckling. Int $\mathrm{J}$ Dev Neurosci, 40: 35-42.

[92] Kim EJ, Ables JL, Dickel LK, Eisch AJ, Johnson JE (2011). Ascl1 (Mash1) defines cells with long-term neurogenic potential in subgranular and subventricular zones in adult mouse brain. PLoS One, 6: e18472.

[93] Dong C, Zhao H, Chen W, Wang L, Zhang L, Zhang $X$, et al. (2012). The dynamic expression of Mash1 in the hippocampal subgranular zone after fimbriafornix transection. Neurosci Lett, 520: 26-31.

[94] Ali FR, Cheng K, Kirwan P, Metcalfe S, Livesey FJ, Barker RA, et al. (2014). The phosphorylation status of Ascl1 is a key determinant of neuronal differentiation and maturation in vivoand in vitro. Development, 141: 2216-2224.

[95] Kim EJ, Battiste J, Nakagawa Y, Johnson JE (2008).
Ascl1 (Mash1) lineage cells contribute to discrete cell populations in CNS architecture. Mol Cell Neurosci, 38: 595-606.

[96] Sommer L, Shah N, Rao M, Anderson DJ (1995). The cellular function of MASH1 in autonomic neurogenesis. Neuron, 15: 1245-1258.

[97] Morrow EM, Furukawa T, Lee JE, Cepko CL (1999). NeuroD regulates multiple functions in the developing neural retina in rodent. Development, 126: 23-36.

[98] Kapoor R, Ghosh H, Nordstrom K, Vennstrom B, Vaidya VA (2011). Loss of thyroid hormone receptor beta is associated with increased progenitor proliferation and NeuroD positive cell number in the adult hippocampus. Neurosci Lett, 487: 199-203.

[99] Li HJ, Ray SK, Singh NK, Johnston B, Leiter AB (2011). Basic helix-loop-helix transcription factors and enteroendocrine cell differentiation. Diabetes Obes Metab, 13: 5-12.

[100] Taylor SM, Alvarez-Delfin K, Saade CJ, Thomas JL, Thummel R, Fadool JM, et al. (2015). The bHLH Transcription Factor NeuroD Governs Photoreceptor Genesis and Regeneration Through Delta-Notch Signaling. Invest Ophthalmol Vis Sci, 56: 7496-7515.

[101] Yan RT, Wang SZ (1998). neuroD induces photoreceptor cell overproduction in vivoand de novo generation in vitro. J Neurobiol, 36: 485-496.

[102] Sato T, Sato F, Kamezaki A, Sakaguchi K, Tanigome R, Kawakami K, et al. (2015). Neuregulin 1 Type IIErbB Signaling Promotes Cell Divisions Generating Neurons from Neural Progenitor Cells in the Developing Zebrafish Brain. PLoS One, 10: e127360.

[103] Soundarapandian MM, Selvaraj V, Lo UG, Golub MS, Feldman DH, Pleasure DE, et al. (2011). Zfp488 promotes oligodendrocyte differentiation of neural progenitor cells in adult mice after demyelination. Sci Rep, 1: 2.

[104] Wang SZ, Dulin J, Wu H, Hurlock E, Lee SE, Jansson K, et al. (2006). An oligodendrocytespecific zinc-finger transcription regulator cooperates with Olig2 to promote oligodendrocyte differentiation. Development, 133: 3389-3398.

[105] Oh HJ, Hwang DW, Youn H, Lee DS (2013). In vivobioluminescence reporter gene imaging for the activation of neuronal differentiation induced by the neuronal activator neurogenin 1 (Ngn1) in neuronal precursor cells. Eur J Nucl Med Mol I, 40: 16071617.

[106] Agasse F, Xapelli S, Coronas V, Christiansen SH, Rosa AI, Sarda-Arroyo L, et al. (2013). Galanin promotes neuronal differentiation in murine subventricular zone cell cultures. Stem Cells Dev, 22: 1693-1708.

[107] Berberoglu MA, Dong Z, Mueller T, Guo S (2009). fezf 2 expression delineates cells with proliferative potential and expressing markers of neural stem cells 
in the adult zebrafish brain. Gene Expr Patterns, 9: 411-422.

[108] Ali F, Hindley C, McDowell G, Deibler R, Jones A, Kirschner M, et al. (2011). Cell cycle-regulated multi-site phosphorylation of Neurogenin 2 coordinates cell cycling with differentiation during neurogenesis. Development, 138: 4267-4277.

[109] Berberoglu MA, Dong Z, Mueller T, Guo S (2009). fezf2 expression delineates cells with proliferative potential and expressing markers of neural stem cells in the adult zebrafish brain. Gene Expr Patterns, 9: 411-422.

[110] Zuccotti A, Le Magueresse C, Chen M, Neitz A, Monyer H (2014). The transcription factor Fezf2 directs the differentiation of neural stem cells in the subventricular zone toward a cortical phenotype. Proc Natl Acad Sci U S A, 111: 10726-10731.

[111] Sakamoto M, Hirata H, Ohtsuka T, Bessho Y, Kageyama R (2003). The basic helix-loop-helix genes Hesr1/Hey1 and Hesr2/Hey2 regulate maintenance of neural precursor cells in the brain. $\mathrm{J}$ Biol Chem, 278: 44808-44815.

[112] Fuke S, Minami N, Kokubo H, Yoshikawa A, Yasumatsu H, Sasagawa N, et al. (2006). Hesr1 knockout mice exhibit behavioral alterations through the dopaminergic nervous system. J Neurosci Res, 84: 1555-1563.

[113] Zhuang J, Wei Q, Lin Z, Zhou C (2015). Effects of ADAM10 deletion on Notch-1 signaling pathway and neuronal maintenance in adult mouse brain. Gene, 555: 150-158.

[114] Yun K, Fischman S, Johnson J, Hrabe DAM, Weinmaster G, Rubenstein JL (2002). Modulation of the notch signaling by Mash1 and Dlx1/2 regulates sequential specification and differentiation of progenitor cell types in the subcortical telencephalon. Development, 129: 5029-5040.

[115] Mendez-Gomez HR, Vicario-Abejon C (2012). The homeobox gene Gsx2 regulates the self-renewal and differentiation of neural stem cells and the cell fate of postnatal progenitors. PLoS One, 7: e29799.

[116] Lopez-Juarez A, Howard J, Ullom K, Howard L, Grande A, Pardo A, et al. (2013). Gsx2 controls region-specific activation of neural stem cells and injury-induced neurogenesis in the adult subventricular zone. Genes Dev, 27: 1272-1287.

[117] Loh KM, van Amerongen R, Nusse R (2016). Generating Cellular Diversity and Spatial Form: Wnt Signaling and the Evolution of Multicellular Animals. Dev Cell, 38: 643-655.

[118] Yang JW, Ma W, Luo T, Wang DY, Lu JJ, Li XT, et al. (2016). BDNF promotes human neural stem cell growth via GSK-3beta-mediated crosstalk with the wnt/beta-catenin signaling pathway. Growth Factors, 34: 19-32.

[119] Singh S, Mishra A, Srivastava N, Shukla S (2017).
MK-801 (Dizocilpine) Regulates Multiple Steps of Adult Hippocampal Neurogenesis and Alters Psychological Symptoms via Wnt/beta-Catenin Signaling in Parkinsonian Rats. ACS Chem Neurosci, 8: 592-605.

[120] Huang GH, Yang XT, Chen K, Xing J, Guo L, Zhu L, et al. (2016). Porf-2 Inhibits Neural Stem Cell Proliferation Through Wnt/beta-Catenin Pathway by Its GAP Domain. Front Cell Neurosci, 10: 85.

[121] Wen J, Hu Q, Li M, Wang S, Zhang L, Chen Y, et al. (2008). Pax6 directly modulate Sox2 expression in the neural progenitor cells. Neuroreport, 19: 413-417.

[122] Sansom SN, Griffiths DS, Faedo A, Kleinjan DJ, Ruan Y, Smith J, et al. (2009). The level of the transcription factor Pax6 is essential for controlling the balance between neural stem cell self-renewal and neurogenesis. PLoS Genet, 5: e1000511.

[123] Jami A, Gadi J, Lee MJ, Kim EJ, Lee MJ, Jung HS, et al. (2013). Pax6 expressed in osteocytes inhibits canonical Wnt signaling. Mol Cells, 35: 305-312.

[124] Kohwi M, Osumi N, Rubenstein JL, Alvarez-Buylla A (2005). Pax6 is required for making specific subpopulations of granule and periglomerular neurons in the olfactory bulb. J Neurosci, 25: 69977003.

[125] Tanaka T, Abe H, Kimura M, Onda N, Mizukami S, Yoshida T, et al. (2016). Developmental exposure to $\mathrm{T}-2$ toxin reversibly affects postnatal hippocampal neurogenesis and reduces neural stem cells and progenitor cells in mice. Arch Toxicol, 90: 20092024.

[126] Martinez-Cerdeno V, Cunningham CL, Camacho J, Keiter JA, Ariza J, Lovern M, et al. (2016). Evolutionary origin of Tbr2-expressing precursor cells and the subventricular zone in the developing cortex. J Comp Neurol, 524: 433-447.

[127] Gangemi RM, Daga A, Marubbi D, Rosatto N, Capra MC, Corte G (2001). Emx2 in adult neural precursor cells. Mech Dev, 109: 323-329.

[128] Gangemi RM, Daga A, Muzio L, Marubbi D, Cocozza S, Perera M, et al. (2006). Effects of Emx2 inactivation on the gene expression profile of neural precursors. Eur J Neurosci, 23: 325-334.

[129] Mariani J, Favaro R, Lancini C, Vaccari G, Ferri AL, Bertolini J, et al. (2012). Emx2 is a dose-dependent negative regulator of Sox 2 telencephalic enhancers. Nucleic Acids Res, 40: 6461-6476.

[130] Suh Y, Obernier K, Holzl-Wenig G, Mandl C, Herrmann A, Worner K, et al. (2009). Interaction between DLX2 and EGFR regulates proliferation and neurogenesis of SVZ precursors. Mol Cell Neurosci, 42: 308-314.

[131] Brill MS, Snapyan M, Wohlfrom H, Ninkovic J, Jawerka M, Mastick GS, et al. (2008). A dlx2- and pax6-dependent transcriptional code for periglomerular neuron specification in the adult 
olfactory bulb. J Neurosci, 28: 6439-6452.

[132] Pruitt SC, Bussman A, Maslov AY, Natoli TA, Heinaman R (2004). Hox/Pbx and Brn binding sites mediate Pax3 expression in vitro and in vivo. Gene Expr Patterns, 4: 671-685.

[133] Fenby BT, Fotaki V, Mason JO (2008). Pax3 regulates Wnt1 expression via a conserved binding site in the 5' proximal promoter. Biochim Biophys Acta, 1779: 115-121.

[134] Liu Y, Zhu H, Liu M, Du J, Qian Y, Wang Y, et al. (2011). Downregulation of Pax3 expression correlates with acquired GFAP expression during NSC differentiation towards astrocytes. FEBS Lett, 585: 1014-1020.

[135] Goulding MD, Chalepakis G, Deutsch U, Erselius JR, Gruss P (1991). Pax-3, a novel murine DNA binding protein expressed during early neurogenesis. EMBO J, 10: 1135-1147.

[136] Sanchez-Ferras O, Bernas G, Laberge-Perrault E, Pilon N (2014). Induction and dorsal restriction of Paired-box 3 (Pax3) gene expression in the caudal neuroectoderm is mediated by integration of multiple pathways on a short neural crest enhancer. Biochim Biophys Acta, 1839: 546-558.

[137] Blake JA, Ziman MR (2013). The characterisation of Pax3 expressant cells in adult peripheral nerve. PLoS One, 8: e59184.

[138] Du Z, Jia D, Liu S, Wang F, Li G, Zhang Y, et al. (2009). Oct4 is expressed in human gliomas and promotes colony formation in glioma cells. Glia, 57: 724-733.

[139] Deleidi M, Cooper O, Hargus G, Levy A, Isacson O (2011). Oct4-induced reprogramming is required for adult brain neural stem cell differentiation into midbrain dopaminergic neurons. PLoS One, 6: e19926.

[140] Jerabek S, Merino F, Scholer HR, Cojocaru V (2014). OCT4: dynamic DNA binding pioneers stem cell pluripotency. Biochim Biophys Acta, 1839: 138-154.

[141] Karalay O, Doberauer K, Vadodaria KC, Knobloch M, Berti L, Miquelajauregui A, et al. (2011). Prospero-related homeobox 1 gene (Prox1) is regulated by canonical Wnt signaling and has a stage-specific role in adult hippocampal neurogenesis. Proc Natl Acad Sci U S A, 108: 58075812.

[142] Lavado A, Lagutin OV, Chow LM, Baker SJ, Oliver G (2010). Prox1 is required for granule cell maturation and intermediate progenitor maintenance during brain neurogenesis. PLoS Biol, 8.

[143] Ruiz IAA, Sanchez P, Dahmane N (2002). Gli and hedgehog in cancer: tumours, embryos and stem cells. Nat Rev Cancer, 2: 361-372.

[144] Marigo V, Roberts DJ, Lee SM, Tsukurov O, Levi T, Gastier JM, et al. (1995). Cloning, expression, and chromosomal location of SHH and IHH: two human homologues of the Drosophila segment polarity gene hedgehog. Genomics, 28: 44-51.

[145] Katoh Y, Katoh M (2005). Comparative genomics on Sonic hedgehog orthologs. Oncol Rep, 14: 10871090.

[146] Son EJ, Ma JH, Ankamreddy H, Shin JO, Choi JY, $\mathrm{Wu}$ DK, et al. (2015). Conserved role of Sonic Hedgehog in tonotopic organization of the avian basilar papilla and mammalian cochlea. Proc Natl Acad Sci U S A, 112: 3746-3751.

[147] Ferent J, Cochard L, Faure H, Taddei M, Hahn H, Ruat M, et al. (2014). Genetic activation of Hedgehog signaling unbalances the rate of neural stem cell renewal by increasing symmetric divisions. STEM CELL REPORTS, 3: 312-323.

[148] Faigle R, Song H (2013). Signaling mechanisms regulating adult neural stem cells and neurogenesis. Biochim Biophys Acta, 1830: 2435-2448.

[149] Kang W, Hebert JM (2015). FGF Signaling Is Necessary for Neurogenesis in Young Mice and Sufficient to Reverse Its Decline in Old Mice. J Neurosci, 35: 10217-10223.

[150] Ferent J, Cochard L, Faure H, Taddei M, Hahn H, Ruat M, et al. (2014). Genetic activation of Hedgehog signaling unbalances the rate of neural stem cell renewal by increasing symmetric divisions. STEM CELL REPORTS, 3: 312-323.

[151] Shi Y, Sun G, Zhao C, Stewart R (2008). Neural stem cell self-renewal. Crit Rev Oncol Hemat, 65: 43-53.

[152] Cho G, Lim Y, Cho IT, Simonet JC, Golden JA (2014). Arx together with FoxA2, regulates Shh floor plate expression. Dev Biol, 393: 137-148.

[153] Briscoe J, Sussel L, Serup P, Hartigan-O'Connor D, Jessell TM, Rubenstein JL, et al. (1999). Homeobox gene Nkx2.2 and specification of neuronal identity by graded Sonic hedgehog signalling. Nature, 398: 622-627.

[154] Qi Y, Cai J, Wu Y, Wu R, Lee J, Fu H, et al. (2001). Control of oligodendrocyte differentiation by the Nkx2.2 homeodomain transcription factor. Development, 128: 2723-2733.

[155] Muraguchi T, Tanaka S, Yamada D, Tamase A, Nakada M, Nakamura H, et al. (2011). NKX2.2 suppresses self-renewal of glioma-initiating cells. Cancer Res, 71: 1135-1145.

[156] Mansour AA, Khazanov-Zisman S, Netser Y, Klar A, Ben-Arie N (2014). Nato3 plays an integral role in dorsoventral patterning of the spinal cord by segregating floor plate/p3 fates via $\mathrm{Nkx} 2.2$ suppression and Foxa2 maintenance. Development, 141: 574-584.

[157] Aguirre A, Gallo V (2004). Postnatal neurogenesis and gliogenesis in the olfactory bulb from NG2expressing progenitors of the subventricular zone. $\mathbf{J}$ Neurosci, 24: 10530-10541.

[158] Cheng W, Yu P, Wang L, Shen C, Song X, Chen J, 
et al. (2015). Sonic hedgehog signaling mediates resveratrol to increase proliferation of neural stem cells after oxygen-glucose deprivation/ reoxygenation injury in vitro. Cell Physiol Biochem, 35: 2019-2032.

[159] Lee J, Platt KA, Censullo P, Ruiz IAA (1997). Gli1 is a target of Sonic hedgehog that induces ventral neural tube development. Development, 124: 25372552.

[160] Ahn S, Joyner AL (2005). In vivoanalysis of quiescent adult neural stem cells responding to Sonic hedgehog. Nature, 437: 894-897.

[161] Galvin KE, Ye H, Erstad DJ, Feddersen R, Wetmore C (2008). Gli1 induces G2/M arrest and apoptosis in hippocampal but not tumor-derived neural stem cells. Stem Cells, 26: 1027-1036.

[162] Stecca B, Ruiz IAA (2009). A GLI1-p53 inhibitory loop controls neural stem cell and tumour cell numbers. EMBO J, 28: 663-676.

[163] Miyazono K, Kamiya Y, Morikawa M (2010). Bone morphogenetic protein receptors and signal transduction. J Biochem, 147: 35-51.

[164] Shi Y, Massague J (2003). Mechanisms of TGF-beta signaling from cell membrane to the nucleus. Cell, 113: 685-700.

[165] Yousef H, Morgenthaler A, Schlesinger C, Bugaj L, Conboy IM, Schaffer DV (2015). Age-Associated Increase in BMP Signaling Inhibits Hippocampal Neurogenesis. Stem Cells, 33: 1577-1588.

[166] Mercier F, Douet V (2014). Bone morphogenetic protein-4 inhibits adult neurogenesis and is regulated by fractone-associated heparan sulfates in the subventricular zone. J Chem Neuroanat, 57-58: 5461.

[167] Fang X, Yu W, Li L, Shao J, Zhao N, Chen Q, et al. (2010). ChIP-seq and functional analysis of the SOX2 gene in colorectal cancers. OMICS, 14: 369384.

[168] Gomez-Lopez S, Wiskow O, Favaro R, Nicolis SK, Price DJ, Pollard SM, et al. (2011). Sox2 and Pax6 maintain the proliferative and developmental potential of gliogenic neural stem cells In vitro. Glia, 59: 1588-1599.

[169] Ferri AL, Cavallaro M, Braida D, Di Cristofano A, Canta A, Vezzani A, et al. (2004). Sox2 deficiency causes neurodegeneration and impaired neurogenesis in the adult mouse brain. Development, 131: 3805-3819.

[170] Hu Q, Zhang L, Wen J, Wang S, Li M, Feng R, et al. (2010). The EGF receptor-sox2-EGF receptor feedback loop positively regulates the self-renewal of neural precursor cells. Stem Cells, 28: 279-286.

[171] Feng R, Zhou S, Liu Y, Song D, Luan Z, Dai X, et al. (2013). Sox2 protects neural stem cells from apoptosis via up-regulating survivin expression. Biochem J, 450: 459-468.
[172] Kang W, Hebert JM (2012). A Sox2 BAC transgenic approach for targeting adult neural stem cells. PLoS One, 7: e49038.

[173] Setoguchi T, Kondo T (2004). Nuclear export of OLIG2 in neural stem cells is essential for ciliary neurotrophic factor-induced astrocyte differentiation. J Cell Biol, 166: 963-968.

[174] Chen LP, Li ZF, Ping M, Li R, Liu J, Xie XH, et al. (2012). Regulation of Olig2 during astroglial differentiation in the subventricular zone of a cuprizone-induced demyelination mouse model. Neuroscience, 221: 96-107.

[175] Copray S, Balasubramaniyan V, Levenga J, de Bruijn J, Liem R, Boddeke E (2006). Olig2 overexpression induces the in vitro differentiation of neural stem cells into mature oligodendrocytes. Stem Cells, 24: 1001-1010.

[176] Ren ZL, Zuo PP (2012). Neural regeneration: role of traditional Chinese medicine in neurological diseases treatment. J Pharmacol Sci, 120: 139-145.

[177] Liu B, Cai G, Yi J, Chen X (2013). Buyang Huanwu Decoction regulates neural stem cell behavior in ischemic brain. Neural Regen Res, 8: 2336-2342.

[178] Sun JH, Gao YM, Yang L, Wang X, Bao LH, Liu WJ, et al. (2007). Effects of Buyang Huanwu Decoction on neurite outgrowth and differentiation of neuroepithelial stem cells. Chin J Physiol, 50: 151156.

[179] Sun J, Bi Y, Guo L, Qi X, Zhang J, Li G, et al. (2007). Buyang Huanwu Decoction promotes growth and differentiation of neural progenitor cells: using a serum pharmacological method. J Ethnopharmacol, 113: 199-203.

[180] Wu L, Ran C, Liu S, Liao L, Chen Y, Guo H, et al. (2013). Jiaweisinisan facilitates neurogenesis in the hippocampus after stress damage. Neural Regen Res, 8: 1091-1102.

[181] Chen MM, Zhao GW, He P, Jiang ZL, Xi X, Xu SH, et al. (2015). Improvement in the neural stem cell proliferation in rats treated with modified "Shengyu" decoction may contribute to the neurorestoration. J Ethnopharmacol, 165: 9-19.

[182] Yang H, Wen SR, Zhang GW, Wang TG, Hu FX, Li XL, et al. (2011). Effects of Chinese herbal medicine Fuzhisan on autologous neural stem cells in the brain of SAMP-8 mice. Exp Gerontol, 46: 628-636.

[183] Park HR, Kim JY, Lee Y, Chun HJ, Choi YW, Shin HK, et al. (2016). PMC-12, a traditional herbal medicine, enhances learning memory and hippocampal neurogenesis in mice. Neurosci Lett, 617: 254-263.

[184] Liu SP, Hsu CY, Fu RH, Huang YC, Chen SY, Lin SZ, et al. (2015). Sambucus williamsii induced embryonic stem cells differentiated into neurons. Biomedicine (Taipei), 5: 3.

[185] Ong WY, Farooqui T, Koh HL, Farooqui AA, Ling 
EA (2015). Protective effects of ginseng on neurological disorders. Front Aging Neurosci, 7: 129.

[186] Jiang YH, Li YB, Zhao XQ, Chen D, Jiang R, Wang SL (2012). Effect of ginsenoside Rg1 on functional expression of human neural stem cells: a patch clamp study. Zhongguo Zhong Yao Za Zhi, 37: 3477-3480.

[187] Li YB, Zhao XQ, Jiang YH, Chen D, Wang SL (2013). Study on molecular target promoting human neural stem cells of ginsenoside Rg1 by gene chip. Zhongguo Zhong Yao Za Zhi, 38: 2701-2705.

[188] Lin T, Liu Y, Shi M, Liu X, Li L, Liu Y, et al. (2012). Promotive effect of ginsenoside $\mathrm{Rd}$ on proliferation of neural stem cells in vivoand in vitro. $\mathrm{J}$ Ethnopharmacol, 142: 754-761.

[189] Chen DF, Meng LJ, Du SH, Zhang HL, Li H, Zhou $\mathrm{JH}$, et al. (2010). (+)-Cholesten-3-one induces differentiation of neural stem cells into dopaminergic neurons through BMP signaling. Neurosci Res, 68: 176-184.

[190] Ning Y, Huang JH, Xia SJ, Bian Q, Chen Y, Zhang XM, et al. (2013). Mechanisms Underlying the Antiproliferative and Prodifferentiative Effects of Psoralen on Adult Neural Stem Cells via DNA Microarray. Evid Based Complement Alternat Med, 2013: 452948.

[191] Huang JH, Cai WJ, Zhang XM, Shen ZY (2014). Icariin promotes self-renewal of neural stem cells: an involvement of extracellular regulated kinase signaling pathway. Chin J Integr Med, 20: 107-115.

[192] Zhuang P, Zhang Y, Cui G, Bian Y, Zhang M, Zhang J, et al. (2012). Direct stimulation of adult neural stem/progenitor cells in vitro and neurogenesis in vivoby salvianolic acid B. PLoS One, 7: e35636.

[193] Zhang N, Kang T, Xia Y, Wen Q, Zhang X, Li H, et al. (2012). Effects of salvianolic acid B on survival, self-renewal and neuronal differentiation of bone marrow derived neural stem cells. Eur J Pharmacol, 697: 32-39.

[194] Tian Y, Liu Y, Chen X, Zhang H, Shi Q, Zhang J, et al. (2010). Tetramethylpyrazine promotes proliferation and differentiation of neural stem cells from rat brain in hypoxic condition via mitogenactivated protein kinases pathway in vitro. Neurosci Lett, 474: 26-31.

[195] Xiao X, Liu Y, Qi C, Qiu F, Chen X, Zhang J, et al. (2010). Neuroprotection and enhanced neurogenesis by tetramethylpyrazine in adult rat brain after focal ischemia. Neurol Res, 32: 547-555.

[196] Si YC, Zhang JP, Xie CE, Zhang LJ, Jiang XN (2011). Effects of Panax notoginseng saponins on proliferation and differentiation of rat hippocampal neural stem cells. Am J Chinese Med, 39: 999.

[197] Tchantchou F, Lacor PN, Cao Z, Lao L, Hou Y, Cui C, et al. (2009). Stimulation of neurogenesis and synaptogenesis by bilobalide and quercetin via common final pathway in hippocampal neurons. J Alzheimers Dis, 18: 787-798.

[198] Chai YS, Hu J, Lei F, Wang YG, Yuan ZY, Lu X, et al. (2013). Effect of berberine on cell cycle arrest and cell survival during cerebral ischemia and reperfusion and correlations with p53/cyclin D1 and PI3K/Akt. Eur J Pharmacol, 708: 44-55.

[199] Lim JS, Yoo M, Kwon HJ, Kim H, Kwon YK (2010). Wogonin induces differentiation and neurite outgrowth of neural precursor cells. Biochem Biophys Res Commun, 402: 42-47.

[200] Wang WW, Lu L, Bao TH, Zhang HM, Yuan J, Miao W, et al. (2016). Scutellarin Alleviates Behavioral Deficits in a Mouse Model of Multiple Sclerosis, Possibly Through Protecting Neural Stem Cells. J Mol Neurosci, 58: 210-220.

[201] Zhuang PW, Cui GZ, Zhang YJ, Zhang MX, Guo H, Zhang JB, et al. (2013). Baicalin regulates neuronal fate decision in neural stem/progenitor cells and stimulates hippocampal neurogenesis in adult rats. CNS Neurosci Ther, 19: 154-162.

[202] Li Y, Zhuang P, Shen B, Zhang Y, Shen J (2012). Baicalin promotes neuronal differentiation of neural stem/progenitor cells through modulating p-stat 3 and bHLH family protein expression. Brain Res, 1429: 36-42.

[203] Wang D, Wong HK, Feng YB, Zhang ZJ (2013). Paeoniflorin, a natural neuroprotective agent, modulates multiple anti-apoptotic and pro-apoptotic pathways in differentiated PC12 cells. Cell Mol Neurobiol, 33: 521-529.

[204] Ma J, Cui B, Ding X, Wei J, Cui L (2015). OverExpression of Cyclin D1 Promotes NSCs Proliferation and Induces the Differentiation into Astrocytes Via Jak-STAT3 Pathways. Neurochem Res, 40: 1681-1690. 